\title{
Using Thermostats for Indoor Climate Control in Offices: The Effect on Thermal Comfort and Heating/Cooling Energy Use
}

\author{
Wang, Haiying; Olesen, Bjarne W.; Kazanci, Ongun Berk
}

Published in:

Energy and Buildings

Link to article, DOI:

10.1016/j.enbuild.2018.12.030

Publication date:

2019

Document Version

Peer reviewed version

Link back to DTU Orbit

Citation (APA):

Wang, H., Olesen, B. W., \& Kazanci, O. B. (2019). Using Thermostats for Indoor Climate Control in Offices: The Effect on Thermal Comfort and Heating/Cooling Energy Use. Energy and Buildings, 188-189, 71-83.

https://doi.org/10.1016/j.enbuild.2018.12.030

\section{General rights}

Copyright and moral rights for the publications made accessible in the public portal are retained by the authors and/or other copyright owners and it is a condition of accessing publications that users recognise and abide by the legal requirements associated with these rights.

- Users may download and print one copy of any publication from the public portal for the purpose of private study or research.

- You may not further distribute the material or use it for any profit-making activity or commercial gain

- You may freely distribute the URL identifying the publication in the public portal 


\section{Accepted Manuscript}

Using Thermostats for Indoor Climate Control in Offices: The Effect on Thermal Comfort and Heating/Cooling Energy Use

Haiying Wang, Bjarne W. Olesen, Ongun B. Kazanci

PII: S0378-7788(18)32185-6

DOI: https://doi.org/10.1016/j.enbuild.2018.12.030

Reference: ENB 8959

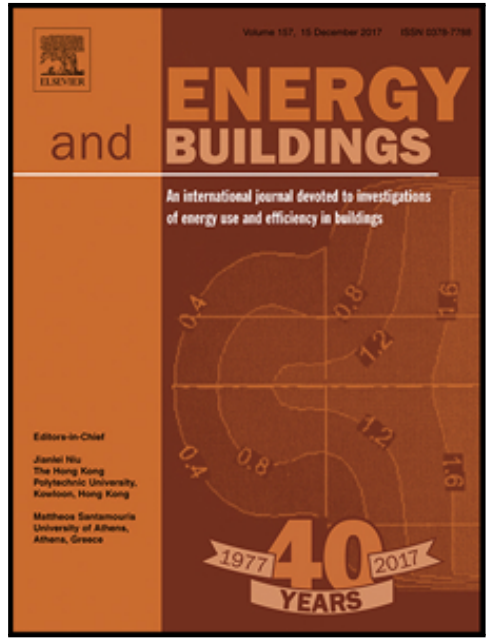

To appear in:

Energy \& Buildings

Received date:

16 July 2018

Revised date:

9 November 2018

Accepted date:

24 December 2018

Please cite this article as: Haiying Wang, Bjarne W. Olesen, Ongun B. Kazanci, Using Thermostats for Indoor Climate Control in Offices: The Effect on Thermal Comfort and Heating/Cooling Energy Use, Energy \& Buildings (2019), doi: https://doi.org/10.1016/j.enbuild.2018.12.030

This is a PDF file of an unedited manuscript that has been accepted for publication. As a service to our customers we are providing this early version of the manuscript. The manuscript will undergo copyediting, typesetting, and review of the resulting proof before it is published in its final form. Please note that during the production process errors may be discovered which could affect the content, and all legal disclaimers that apply to the journal pertain. 


\section{Highlights}

- Two thermostat controls based on air/operative temperature were studies in offices.

- The two controls were compared in convective/radiant systems in three locations.

- Convective system with operative temperature control was better in thermal comfort.

- The controls had less impact on thermal comfort and energy use to radiant systems.

- Different thermostat control was suggested based on system type and orientation. 


\title{
Using Thermostats for Indoor Climate Control in Offices: The Effect on Thermal Comfort and Heating/Cooling Energy Use
}

\author{
Haiying Wang ${ }^{\mathrm{a}, \mathrm{b},{ }^{*} \quad \text { Bjarne W. Olesen }}{ }^{\mathrm{a}} \quad$ Ongun B. Kazanci ${ }^{\mathrm{a}}$
}

a International Centre for Indoor Environment and Energy, Department of Civil Engineering, Technical University of Denmark, Nils Koppels Allé, Building 402, 2800 Kgs. Lyngby, Denmark

b Department of Environment and Municipal Engineering, Qingdao University of Technology, No. 11 Fushun Road, Qingdao, China

* Corresponding author

E-mail: why3305@126.com (Haiying Wang); bwo@byg.dtu.dk (B.W. Olesen); onka@byg.dtu.dk (Ongun B. Kazanci)

\section{Abstract}

The most commonly used thermostat control variable in heating, ventilating and air-conditioning systems is air temperature. However, people's thermal comfort responds to operative temperature more directly than air temperature. Will the adoption of operative temperature based control lead to better thermal comfort and how will this affect the energy use? To get a better understanding about these questions, simulations have been performed based on three heating and cooling systems in three different geographical locations (Copenhagen, Paris and Rome). The three system are fan-coil system representing convective system and two radiant systems: floor heating/cooling system and radiant ceiling heating/cooling panel system.

The results showed that air temperature based thermostat control and operative temperature based thermostat control had different impacts on fan-coil system and radiant systems. For fan-coil system, the use of operative temperature based thermostat control had better thermal comfort conditions and higher energy use than that of air temperature based thermostat control. For the two radiant systems, the results were the opposite. The results were almost the same in different locations. Besides, the thermal comfort difference between the two controls of north office was smaller than that of south office. For fan-coil system, in south office, compared with air temperature based thermostat control, the hours of Cat. I ( $-0.2 \leqslant \mathrm{PMV} \leqslant 0.2)$ increased $8.3 \%$ for building in Copenhagen, $8.8 \%$ for Paris and $14.2 \%$ for Rome and hours of Cat. IV (PMV $<-0.7$ or PMV $>0.7)$ decreased $2.5 \%, 3.9 \%$ and $7.1 \%$ respectively when operative temperature based thermostat control was used. Meanwhile, total energy supply increased $13.7 \%$ in Copenhagen, $14.3 \%$ in Paris and $12.7 \%$ in Rome. For radiant systems, the total energy use reduced $3.3 \%$ to $8.3 \%$ depending on location and type of system when operative temperature based control was used. With this reduction of energy use, thermal comfort in 
south office was still within recommended criteria in international standards in most cases. Based on the results, it is suggested that air temperature based thermostat control be used in fan-coil system and operative temperature based thermostat control be used in radiant system in north office. For south office, operative temperature based thermostat control was considered better for fan-coil system and could be more energy efficient when utilized in radiant heating and cooling systems.

Key words Room temperature control, air temperature, operative temperature, energy use, thermal comfort, heating/cooling system, convective system, radiant system

\section{Introduction}

In HVAC (heating, ventilating and air-conditioning) systems the most commonly used parameter to control thermal environment in buildings is the air temperature $\left(T_{a}\right)$. This is accomplished either by a thermostat installed in each zone (room) or by a 'central' thermostat controlling the conditions of several zones based on the average air temperature set point of those zones. Control of the air temperature alone is not sufficient in some situations. For example, during summer, people in perimeter zones of highly glazed buildings are generally uncomfortable because of radiation from sun or high temperature of the window surface. The effects of thermal radiation on thermal comfort have long been known, and were quantified by Hardy [1] and Gagge et al. [2]. The concept of "operative temperature" ( $\left.T_{\mathrm{op}}\right)$ was introduced earlier by Gagge [3] to account for the combined effect of mean radiant temperature $\left(T_{r}\right)$, and air temperature. In all existing standards that deal with criteria for the indoor environment, requirements are expressed using Operative Temperature as room temperature [4-6].

The following equation is used to calculate $T_{\text {op }}[4]$ :

$T_{o p}=\frac{h_{c} \cdot T_{a}+h_{r} \cdot T_{r}}{h_{c}+h_{r}}$

Where $h_{c}$ is convective heat transfer coefficient for the human body, $W /\left(m^{2} . K\right) ; h_{r}$ is linear radiative heat transfer coefficient for the human body, $\mathrm{W} /\left(\mathrm{m}^{2} \cdot \mathrm{K}\right)$.

In equation (1), $h_{c}$ is influenced by air velocity. In most indoor office spaces with low air velocities $(<0.2 \mathrm{~m} / \mathrm{s})$, the equation can be simplified to:

$T_{o p}=0.5 \times\left(T_{a}+T_{r}\right)$

As $T_{\text {op }}$ is more closely related to the influence of room temperature on thermal comfort compared to $T_{a}$, the use of $T_{o p}$ based thermostat control (TC- $T_{o p}$ ) have been studied and compared with $\mathrm{T}_{\mathrm{a}}$ based thermostat control $\left(\mathrm{TC}-\mathrm{T}_{\mathrm{a}}\right.$ ) in a few research papers.

Jain et al. [7] compared the effects of the two controls on energy use in perimeter zones of highly glazed buildings in New Delhi (India) through simulation. Their results had shown that energy use in highly glazed buildings can be under-estimated by the use of TC- $\mathrm{T}_{\mathrm{a}}$. In 
simulation study, Julien et al. [8] found an increase of $18.7 \%$ on heating load when TC-Top was compared with $\mathrm{TC}-\mathrm{T}_{\mathrm{a}}$. Another simulation study recorded an increase of $7 \%$ in an office building in Hong Kong [9]. From these studies, the use of $\mathrm{TC}^{-\mathrm{T}_{\mathrm{a}}}$ or $\mathrm{TC}-\mathrm{T}_{\text {op }}$ would influence cooling /heating energy use.

Kontes et al. [10] studied two different buildings to study the effect of TC- $\mathrm{T}_{\mathrm{a}}$ and TC- $\mathrm{T}_{\text {op }}$ on thermal comfort. Based on their simulation results, they confirmed the inability of widely-used air temperature control methodologies to provide a structured and systematic way of representing and controlling thermal comfort in buildings. They also concluded that simply adoption of TC-T $\mathrm{T}_{\text {op }}$ could not ensure thermal comfort.

Currently, most studies are based on simulations. Theoretically, the basic difference between two thermostat controls, in simulation, is that during TC- $\mathrm{T}_{\mathrm{a}}, \mathrm{T}_{\mathrm{a}}$ is maintained at a fixed design value (set-point) within a dead band, $T_{\mathrm{op}}$ is allowed to fluctuate. And it would be vice versa if $\mathrm{TC}-\mathrm{T}_{\mathrm{op}}$ is used [9]. The impact of $\mathrm{TC}-\mathrm{T}_{\mathrm{a}}$ and $\mathrm{TC}-\mathrm{T}_{\mathrm{op}}$ on thermal comfort and energy use would be small if the difference between $T_{a}$ and $T_{o p}$ was small. For convective heating/cooling system where radiant surfaces (cool/warm windows etc.) are involved in rooms, $T_{a}$ may be different from $T_{o p}$. When radiant heating/cooling system are used, in summer the radiant cooler surface may compensate for the warm window $[11,12]$, while in winter a heated surface may compensate for a cool window. This difference between convective system and radiant system may lead to different effect of TC- $\mathrm{T}_{\mathrm{a}}$ and TC- $\mathrm{T}_{\mathrm{op}}$, which should be studied intensively.

This paper summarizes the results of dynamic computer simulations of energy use and indoor thermal environment of offices conditioned by means of different HVAC systems: a commonly used fan-coil system (FCS), floor heating/cooling system (FHCS), and radiant ceiling heating/cooling panel system (CHCPS). The potential influence on thermal conditions and energy use resulting from using the selected systems was quantified.

\section{Methods}

The simulations described in this paper were performed using the IDA ICE (version: 4.8) building simulation tool [13]. It allows simultaneous performance assessments of all building characteristics such as facade and wall construction, window glazing, HVAC systems, controls, indoor air quality, human thermal comfort and energy use.

\subsection{Building model}

The building model used in all simulations included a central module of an office building with two offices separated by a corridor (Fig.1). Both the corridor and each of the offices were treated as separate zones. The selection of the building module was based on earlier work by Olesen and Dossi [14], and also used in other simulations [15,16]. The total floor area used in modeling was $48.4 \mathrm{~m}^{2}$. The building was a light construction with steel frame and thermal insulation. The thermal characteristics of the building components 
are given in Table 1. The orientation of offices were north and south representing extreme comparison of solar radiation conditions. All spaces adjacent to the central module were assumed to have the same internal temperatures as the test space, therefore only heat transmission through external walls was considered.

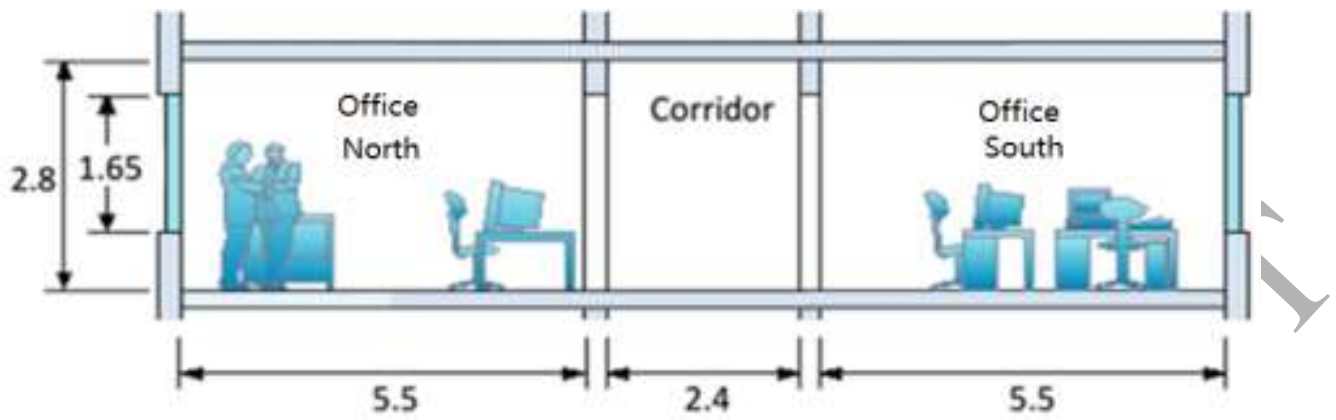

Room width $=3.6 \mathrm{~m}$, window portion of the external wall $=30 \%$

Fig.1 Section of the room module (reproduced from Olesen and Dossi [14]). Dimensions in $\mathrm{m}$.

Table 1 Thermal characteristics of the building components [15]

\begin{tabular}{l|l|c|c|c|c|c|c}
\hline $\begin{array}{c}\text { Building } \\
\text { construction }\end{array}$ & $\begin{array}{c}\text { Building } \\
\text { components }\end{array}$ & $\begin{array}{c}\text { Thickness } \\
(\mathrm{mm})\end{array}$ & $\begin{array}{c}\text { Density } \\
\left(\mathrm{kg} / \mathrm{m}^{3}\right)\end{array}$ & $\begin{array}{c}\text { Thermal } \\
\text { conductivity } \\
(\mathrm{W} / \mathrm{mK})\end{array}$ & $\begin{array}{c}\text { Specific } \\
\text { heat } \\
\text { capacity } \\
(\mathrm{Wh} / \mathrm{kgK})\end{array}$ & $\begin{array}{c}\text { Emissivity } \\
\text { dim. less }\end{array}$ & $\begin{array}{c}\text { Overall } \\
\mathrm{u} \\
\text { value } \\
\left(\mathrm{W} / \mathrm{m}^{2}\right. \\
\mathrm{K})\end{array}$ \\
\hline Floor/ceiling & Screed & 45 & 2000 & 1.4 & 0.28 & 0.94 & 1.238 \\
& Acoustic & 20 & 50 & 0.04 & 0.42 & & \\
& insulation & 180 & 2400 & 2.1 & 0.28 & & \\
& Concrete & 2 & 2600 & 200 & 0.28 & 0.30 & 0.375 \\
\hline Outside wall & Aluminum & 100 & 30 & 0.04 & 0.28 & & \\
& Insulation & 2 & 2600 & 200 & 0.28 & & \\
& Aluminum & 25 & 900 & 0.21 & 0.28 & 0.82 & 0.482 \\
\hline Internal wall & Plasterboard & 60 & 20 & 0.04 & 0.28 & & \\
& Insulation & 25 & 900 & 0.21 & 0.28 & & 2.09 \\
\hline
\end{tabular}

\subsection{Locations and meteorological data}

Simulations were performed for three locations in Europe, each representing a different climate: Copenhagen (cold winter and cool summer), Paris (less-cold winter and warm summer) and Rome (warm winter and hot summer). The Typical meteorological year design data from ASHRAE Fundamentals 2013 [17] was used as climate data input. Average monthly outdoor temperatures of the three cities are shown in Fig.2.

In this study, the dynamic simulation of each case was carried out throughout a whole year (from $1^{\text {st }}$ Jan. to $31^{\text {st }}$ Dec. 2018, considering eleven public holidays besides normal 
weekends) to compare the different effects of the two control modes on the cooling and heating conditions.

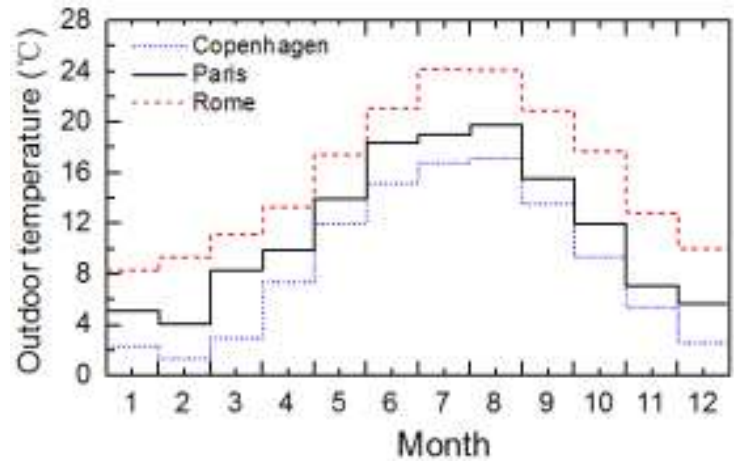

Fig.2 Average monthly outdoor temperature.

Total internal heat load in the office zones was considered approximately $630 \mathrm{~W} /$ zone (32 $\mathrm{W} / \mathrm{m}^{2}$ ), which was set according to reference [15]. The load included heat production by two occupants, present in the building during week days from 8:00 to 12:00 and from 13:00 to 17:00. Occupants' metabolic rate was considered to be approximately $1.2 \mathrm{met}$; that corresponds to about $238 \mathrm{~W}$ [5]. Clothing insulation was set to 0.5 clo for simulations corresponding to the cooling period and 1.0 clo during the heating period. Office equipment (two computers and a printer) were estimated to produce $350 \mathrm{~W}$ (long wave radiation fraction 50\%) and ceiling light $50 \mathrm{~W}$ (convective fraction $50 \%$ ) of heat. Heat loads from equipment and light had the same time schedule as occupants as it could be assumed that people switched off the light and their computers during lunch break. Moisture production by occupants was taken into account in the zone model, calculation of the moisture load was done according to EN ISO 7730 [5]. In addition, there was $100 \mathrm{~W}$ ceiling light as the only heat source in the corridor zone.

Windows in the office zones were equipped with only internal solar shading (light woven drape). When the solar radiation incident on an inside glass pane exceeded $200 \mathrm{~W} / \mathrm{m}^{2}$, internal drape would be activated. When the internal shading was drawn, the total shading coefficient of the window was multiplied by a factor of 0.71 and the short-wave shading coefficient of the window by a factor of 0.67 . The effect of the internal blinds on the $\mathrm{U}$-value of the window was considered by a coefficient of 0.87 . The solar shading devices had simple two-position (on/off) control.

\subsection{Description of the simulated systems}

For each type of simulated HVAC system, the indoor units cooperated with a ventilation system with heat recovery (effectiveness was 0.6 ). The ventilation system operated on weekdays from 8:00 to12:00 and 13:00 to 17:00 with lunch break. The supply airflow was $2 \mathrm{~L} /\left(\mathrm{s} . \mathrm{m}^{2}\right)$, which was about 2.6 air change per hour $(\mathrm{ACH})$, (to keep acceptable indoor air quality [18]) with constant supply temperature of $19{ }^{\circ} \mathrm{C}$. The supply/exhaust airflow ratio was 1. Besides this mechanical ventilation, natural infiltration was set as $0.5 \mathrm{ACH}$ under 
pressure difference of $50 \mathrm{pa}$, which was $0.39 \mathrm{~L} /\left(\mathrm{s} . \mathrm{m}^{2}\right)$ under this pressure difference. In the simulation, this natural infiltration would change according to the variation of climate file and would much lower than $0.5 \mathrm{ACH}$.

The temperature of offices and corridor was set to $25 \pm 1^{\circ} \mathrm{C}$ for cooling and $21 \pm 1^{\circ} \mathrm{C}$ for heating. The cooling would be turned on when the temperature is higher than $26^{\circ} \mathrm{C}$ and be turned off when the temperature is lower than $24^{\circ} \mathrm{C}$. The heating would be turned on when the temperature is lower than $20^{\circ} \mathrm{C}$ and be turned off when higher than $22{ }^{\circ} \mathrm{C}$. There was sensor of $T_{a}$ or $T_{\text {op }}$ in each zone to achieve individual zone control.

(a) Fan-Coil System (FCS)

The main aim of FCS simulation was to compare the effect of two thermostat controls on a conventional system, which does not involve any radiant heating or cooling surfaces. The indoor unit of FCS had constant air volume with air flow (circulating air) rate of $5 \mathrm{~L} /\left(\mathrm{s} . \mathrm{m}^{2}\right.$ ) for each zone. The supply air temperature would be adjusted according to the difference between the set point and tested room temperature. The fan-coils operated during occupied hours and were totally turned down during lunch break. The supply water temperature was $15^{\circ} \mathrm{C}$ for cooling and $40{ }^{\circ} \mathrm{C}$ for heating. The delta $\mathrm{T}$ of water circulation was $5{ }^{\circ} \mathrm{C}$ under design power for cooling and $10^{\circ} \mathrm{C}$ for heating under design power.

(b) Floor Heating/Cooling System (FHCS)

This is one of the typical radiant HVAC systems in buildings with water pipes buried in the concrete floors. In the simulation, water in the floor pipes circulated from 7:00 to 17:00 during weekdays (an hour earlier before occupancy) considering the slower heat transfer process of this type of system. In the water circuit of each zone, a three-way valve was used to control the mass flow. The supply water temperature for cooling was $15^{\circ} \mathrm{C}$ and $40^{\circ} \mathrm{C}$ for heating. The delta $\mathrm{T}$ of Water circulation was $5{ }^{\circ} \mathrm{C}$ under design power for both heating and cooling. In the simulation the lowest floor surface temperature was $21.8^{\circ} \mathrm{C}$ and there was no condensation.

(c) Radiant Ceiling Heating/Cooling Panel system (CHCPS)

This is another radiant HVAC system, in which water pipes run through suspended panels below the ceiling. In this system, the panel is not embedded in the building construction. The operation time was same as the FHCS. The set point of supply water for cooling was $19^{\circ} \mathrm{C}$ and $40^{\circ} \mathrm{C}$ for heating. The delta $\mathrm{T}$ of water circulation was $3^{\circ} \mathrm{C}$ for cooling and $10^{\circ} \mathrm{C}$ for heating at design power. Considering the direct contact of cooling panel with air, to avoid condensation the supply water temperature of CHCPS was set higher than FCS and FHCS.

\subsection{Analysis of the results}

The amount of the energy used to condition the indoor space in the building module was determined and compared for all simulated HVAC systems. In the analysis, only two parts of energy (kWh) delivered to a particular HVAC system were considered: (1) zone 
heating/cooling - thermal energy supplied to indoor units; (2) ventilation system heating/cooling - thermal energy supplied to heating/cooling coils in air handling units to condition the air supplied to the zones. Since the main concern was to compare the effect of two thermostat controls, other energy cost by fans, pumps etc. was not included. The annual heating/cooling energy use per square meter of the space $\left(\mathrm{kWh} / \mathrm{m}^{2} . \mathrm{yr}\right)$ was calculated.

For one specific system in different locations, percent change of total cooling and heating energy use, $\Delta \mathrm{E}$, was calculated according to Eq.(3).

$\Delta E=100 \times \frac{E_{T a}-E_{T o p}}{E_{T a}}$

Where $E_{T a}$ is annual heating or cooling energy use $\left(\mathrm{kWh} / \mathrm{m}^{2} . \mathrm{yr}\right)$ with $\mathrm{TC}-\mathrm{T}_{\mathrm{a}}$ and $\mathrm{E}_{\mathrm{Top}}$ is annual heating or cooling energy use $\left(\mathrm{kWh} / \mathrm{m}^{2}\right.$.yr) with TC-T op for a specific HVAC system. The PMV index was calculated by the simulation software based on air temperature, mean radiant temperature, air humidity and air velocity in the office zones, clothing insulation and metabolic heat production [5]. In the calculation of PMV, the velocity in zones was assumed to be $0.1 \mathrm{~m} / \mathrm{s}$. Statistics of the thermal comfort conditions was conducted to determine the ability of the simulated systems to keep the comfort limits specified by current standards (Table 2). The thermal comfort conditions were evaluated for both of the zones (north and south office).

Table 2 Recommended thermal comfort levels according to standards $[5,6,19]$

\begin{tabular}{l|l|l|l|l}
\hline \multirow{2}{*}{ Category } & \multicolumn{3}{l}{ Thermal state of body as a whole } \\
\cline { 2 - 5 } & PMV & PPD $(\%)$ & \multicolumn{2}{l}{ Operative temperature $\left({ }^{\circ} \mathrm{C}\right)$} \\
\cline { 3 - 5 } & & \multicolumn{2}{l}{ During cooling } & During heating \\
\hline I & -0.2 to 0.2 & $<6$ & $23.5-25.5$ & $21.0-23.0$ \\
\hline II & -0.5 to 0.5 & $<10$ & $23.0-26.0$ & $20.0-24.0$ \\
\hline III & -0.7 to 0.7 & $<15$ & $22.0-27.0$ & $19.0-25.0$ \\
\hline IV & $<-0.7$ or $>0.7$ & $>15$ & $<22.0$ or $>27.0$ & $<19.0$ or $>25.0$ \\
\hline
\end{tabular}

\section{Results and discussions}

\subsection{Cooling and heating energy use}

The annual heating and cooling energy of the simulated HVAC systems for three locations is summarized in Table 3. 
Table 3 Annual heating and cooling energy use

\begin{tabular}{|c|c|c|c|c|c|c|c|c|c|}
\hline \multirow[t]{2}{*}{ Location } & \multirow{2}{*}{$\begin{array}{l}\text { Type of } \\
\text { system }\end{array}$} & \multirow{2}{*}{$\begin{array}{l}\text { Type of } \\
\text { control }\end{array}$} & \multicolumn{3}{|c|}{ Cooling (kWh/m².yr) } & \multicolumn{3}{|c|}{ Heating $\left(\mathrm{kWh} / \mathrm{m}^{2} \cdot \mathrm{yr}\right)$} & \multirow{2}{*}{$\begin{array}{l}\text { Total cooling } \\
\text { and heating } \\
\left(\mathrm{kWh} / \mathrm{m}^{2} . \mathrm{yr}\right)\end{array}$} \\
\hline & & & Ventilation & Indoor units & Total & Ventilation & $\begin{array}{l}\text { Indoor } \\
\text { units }\end{array}$ & Total & \\
\hline \multirow{9}{*}{$\begin{array}{l}\text { Copenha } \\
\text { gen }\end{array}$} & \multirow[t]{3}{*}{ FCS } & $\mathrm{TC}-\mathrm{T}_{\mathrm{a}}$ & 1.44 & 13.03 & 14.47 & 9.5 & 1.77 & 11.27 & 25.74 \\
\hline & & TC-T & 1.39 & 15.68 & 17.07 & 9.23 & 2.96 & 12.19 & 29.26 \\
\hline & & $\Delta \mathrm{E}$ & $3.5 \%$ & $20.3 \%^{c}$ & $18.0 \%$ & $2.8 \%$ & $67.2 \%$ & $8.2 \%$ & $-13.7 \%$ \\
\hline & \multirow[t]{3}{*}{ FHCS } & $\mathrm{TC}-\mathrm{T}_{\mathrm{a}}$ & 1.46 & 15.76 & 17.22 & 8.71 & 4.71 & 13.42 & 30.64 \\
\hline & & TC-Top & 1.46 & 14.25 & 15.7 & 8.61 & 4.72 & 13.33 & 29.03 \\
\hline & & $\Delta \mathrm{E}$ & $0.0 \%$ & $9.6 \%$ & $8.8 \%$ & $1.1 \%$ & $-0.2 \%$ & $0.7 \%$ & $5.3 \%$ \\
\hline & \multirow[t]{3}{*}{ CHCPS } & $\mathrm{TC}-\mathrm{T}_{\mathrm{a}}$ & 1.42 & 16.48 & 17.9 & 8.33 & 6.45 & 14.78 & 32.68 \\
\hline & & TC-Top & 1.43 & 14.86 & 16.29 & 8.52 & 5.17 & 13.69 & 29.98 \\
\hline & & $\Delta \mathrm{E}$ & $-0.7 \%$ & $9.8 \%$ & $9.0 \%$ & $-2.3 \%$ & $19.8 \%$ & $7.4 \%$ & $8.3 \%$ \\
\hline \multirow[t]{9}{*}{ Paris } & \multirow[t]{3}{*}{ FCS } & $\mathrm{TC}-\mathrm{T}_{\mathrm{a}}$ & 4.47 & 17.92 & 22.39 & 5.25 & 0.39 & 5.64 & 28.03 \\
\hline & & TC-T & 4.33 & 21.5 & 25.83 & 5.33 & 0.88 & 6.21 & 32.04 \\
\hline & & $\Delta \mathrm{E}$ & $3.1 \%$ & $-20.0 \%$ & $-15.4 \%$ & $-1.5 \%$ & $-125.6 \%$ & $-10.1 \%$ & $-14.3 \%$ \\
\hline & \multirow[t]{3}{*}{ FHCS } & $\mathrm{TC}-\mathrm{T}_{\mathrm{a}}$ & 4.52 & 21.04 & 25.56 & 5.05 & 1.75 & 6.81 & 32.37 \\
\hline & & TC- $T_{o p}$ & 4.54 & 19.28 & 23.82 & 4.96 & 1.62 & 6.58 & 30.4 \\
\hline & & $\Delta \mathrm{E}$ & $-0.4 \%$ & $8.4 \%$ & $6.8 \%$ & $1.8 \%$ & $7.4 \%$ & $3.4 \%$ & $6.1 \%$ \\
\hline & \multirow[t]{3}{*}{ CHCPS } & TC-Ta & 4.35 & 21.96 & 26.31 & 4.9 & 2.63 & 7.53 & 33.84 \\
\hline & & TC-T & 4.37 & 20.07 & 24.44 & 4.93 & 1.84 & 6.77 & 31.21 \\
\hline & & $\Delta \mathrm{E}$ & $-0.5 \%$ & $8.6 \%$ & $7.1 \%$ & $-0.6 \%$ & $30.0 \%$ & $10.1 \%$ & $7.8 \%$ \\
\hline \multirow[t]{9}{*}{ Rome } & \multirow[t]{3}{*}{ FCS } & $\mathrm{TC}-\mathrm{T}_{\mathrm{a}}$ & 19.95 & 32.45 & 52.4 & 0.95 & 0.02 & 0.97 & 53.37 \\
\hline & & TC-Top & 19.16 & 39.67 & 58.83 & 1.2 & 0.13 & 1.33 & 60.16 \\
\hline & & & $4.0 \%$ & $-22.2 \%$ & $-12.3 \%$ & $-26.3 \%$ & $-550.0 \%$ & $-37.1 \%$ & $-12.7 \%$ \\
\hline & \multirow[t]{3}{*}{ FHCS } & $\mathrm{TC}-\mathrm{T}_{\mathrm{a}}$ & 20.26 & 35.11 & 55.37 & 1.05 & 0.19 & 1.24 & 56.61 \\
\hline & & $\mathrm{TC}-\mathrm{T}_{\mathrm{op}}$ & 20.36 & 33.27 & 53.63 & 0.99 & 0.14 & 1.13 & 54.76 \\
\hline & & $\Delta \mathrm{E}$ & $-0.5 \%$ & $5.2 \%$ & $3.1 \%$ & $5.7 \%$ & $26.3 \%$ & $8.9 \%$ & $3.3 \%$ \\
\hline & \multirow[t]{3}{*}{ CHCPS } & $\mathrm{TC}-\mathrm{T}_{\mathrm{a}}$ & 19.71 & 36.96 & 56.67 & 1.06 & 0.27 & 1.33 & 58 \\
\hline & & TC-T & 19.94 & 34.88 & 54.82 & 1.01 & 0.16 & 1.17 & 55.99 \\
\hline & & $\Delta \mathrm{E}$ & $-1.2 \%$ & $5.6 \%$ & $3.3 \%$ & $4.7 \%$ & $40.7 \%$ & $12.0 \%$ & $3.5 \%$ \\
\hline
\end{tabular}

( ${ }^{\mathrm{C}}$ Percent change of $\Delta \mathrm{E}$ beyond the range of $\pm 5 \%$ are printed in bold.)

To make the comparison more clearly, these data are also shown in Fig.3.

As expected that the lowest cooling energy use was observed in Copenhagen and the highest in Rome, while the highest heating energy use was in Copenhagen and the lowest in Rome. With a moderate climate, both cooling and heating energy in Paris were in the middle of the other two cities. 
In general, for FCS less heating and cooling energy were supplied with TC- $\mathrm{T}_{\mathrm{a}}$ for the three locations, while for radiant systems more energy was used with $\mathrm{TC}-\mathrm{T}_{\mathrm{a}}$. For the three systems, the cooling energy difference between the two controls was higher than $5 \%$ when the building was located in Copenhagen and Paris. For Rome, the difference was less than $5 \%$ for all systems expect FCS.

The difference of simulated heating energy use between the two controls was higher than $5 \%$ for FCS and CHCPS in Copenhagen and Paris, while for FHCS, the difference was less than $5 \%$. In Rome, the heating energy use between $\mathrm{TC}^{-} \mathrm{T}_{\mathrm{a}}$ and $\mathrm{TC}-\mathrm{T}_{\text {op }}$ was larger than $5 \%$ for all systems. However, the total heating energy used in Rome was very small, less than $10 \%$ of that of Copenhagen, therefore this difference would not have significant meaning.

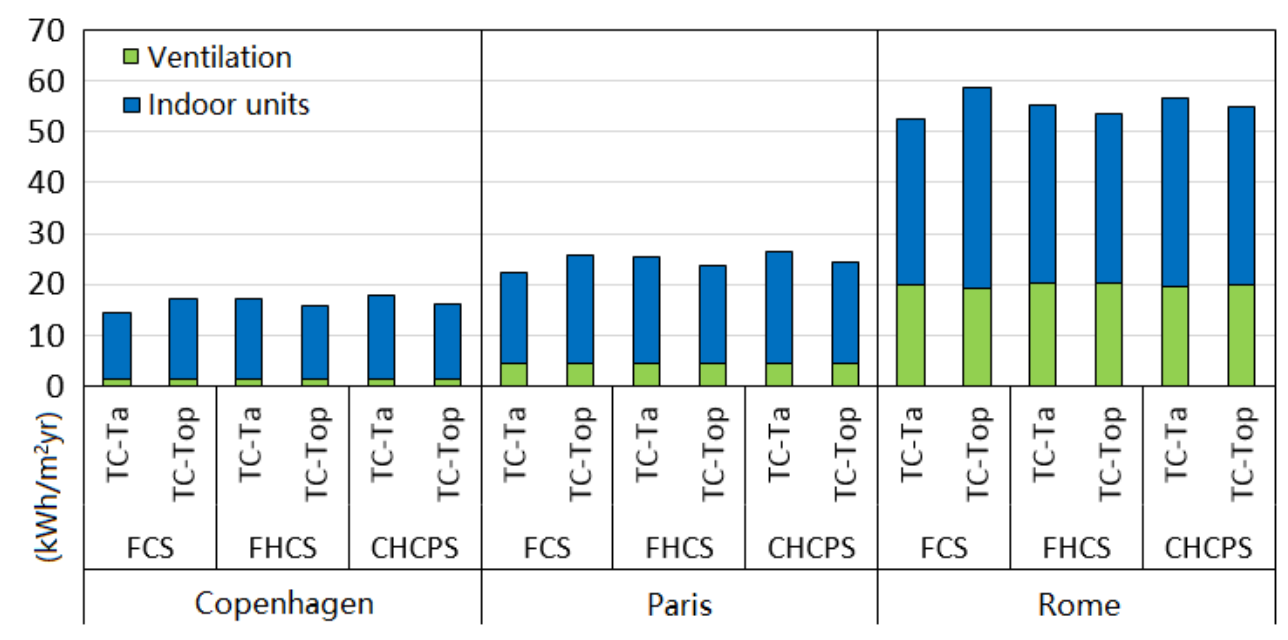

(a) Cooling energy use in simulated year

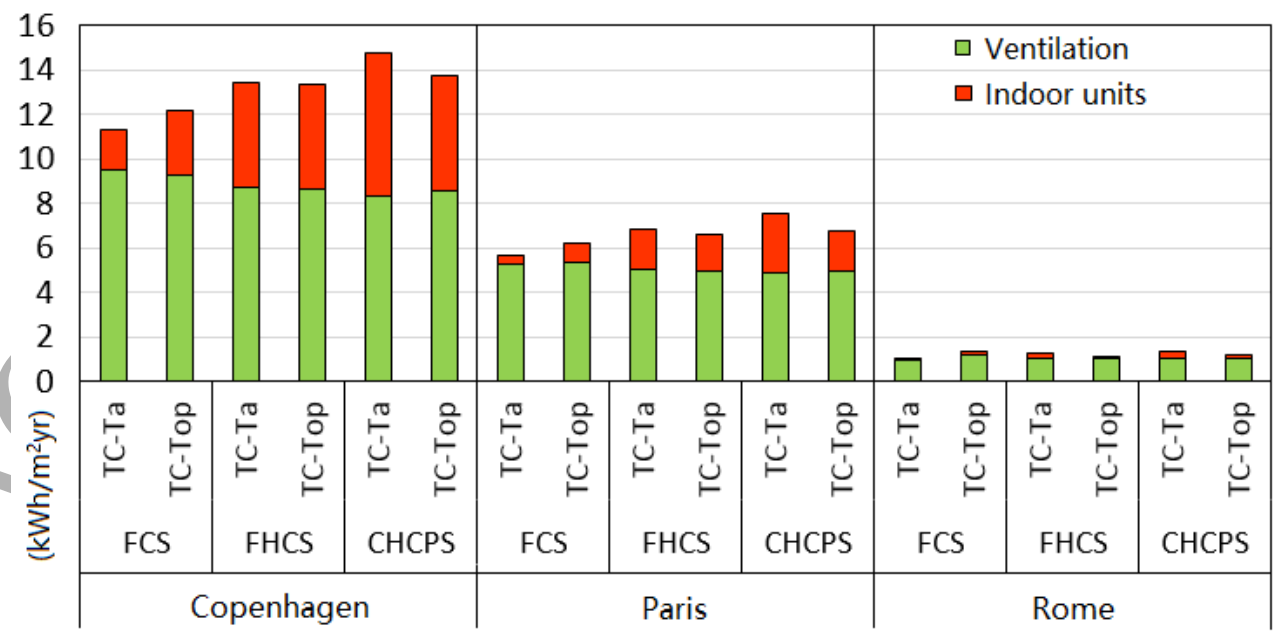

(b) Heating energy use in simulated year

Fig.3 Annual heating and cooling energy use

The energy use on typical days were further compared. Mondays and Wednesdays were chosen in winter and summer respectively, because Monday is the first day after weekend with heavy loads, while Wednesday is a mid-weekday with relatively moderate loads. The 
hourly energy supply on $15^{\text {th }}$ Jan. (Monday), $17^{\text {th }}$ (Wednesday), $16^{\text {th }}$ Jul. (Monday) and $18^{\text {th }}$ (Wednesday) are shown in Fig.4. As ventilation system was turned off during lunch break (12:00-13:00), there were sudden drop of heating/cooling energy during this period. Besides, FCS was also turned off during this time and the fluctuation of FCS was more significant than radiant systems.

The change of heating or cooling energy between the two controls showed the same tendency with that of the whole year.

On $15^{\text {th }}$ Jan., for FCS the total heating energy with TC- $\mathrm{T}_{\mathrm{a}}$ was smaller than that of $\mathrm{TC}-\mathrm{T}_{\mathrm{op}}$, and for FHCS and CHCPS the heating energy with $\mathrm{TC}-\mathrm{T}_{\mathrm{a}}$ became larger than that of TC- $T_{\text {op }}$ in both Copenhagen and Paris. It could be noticed that the heating energy became smaller in the afternoon. In fact, in the afternoon heating energy was supplied only for ventilation (to heat the outdoor air to $19^{\circ} \mathrm{C}$ ). In Rome, heating energy was only supplied in the morning and in the afternoon cooling was needed. Because of the internal heat gains in the offices, the demand for heating would decrease when the outdoor temperature rises and the solar radiation increases in the afternoon. For a city like Rome, which has warm climate in winter cooling was, therefore, needed in the simulation.

On $16^{\text {th }}$ Jul., for FCS the total cooling energy with TC-Ta was smaller than that with TC-Top for the three locations. For FHCS and CHCPS the cooling energy with TC- $\mathrm{T}_{\mathrm{a}}$ became higher than that of TC- $\mathrm{T}_{\text {op }}$ when the building was located in Copenhagen and Paris. When located in Rome, the cooling energy difference between the two controls could be neglected for radiant systems.

Compared to Mondays, on Wednesdays heating/cooling energy became smaller in the three locations.
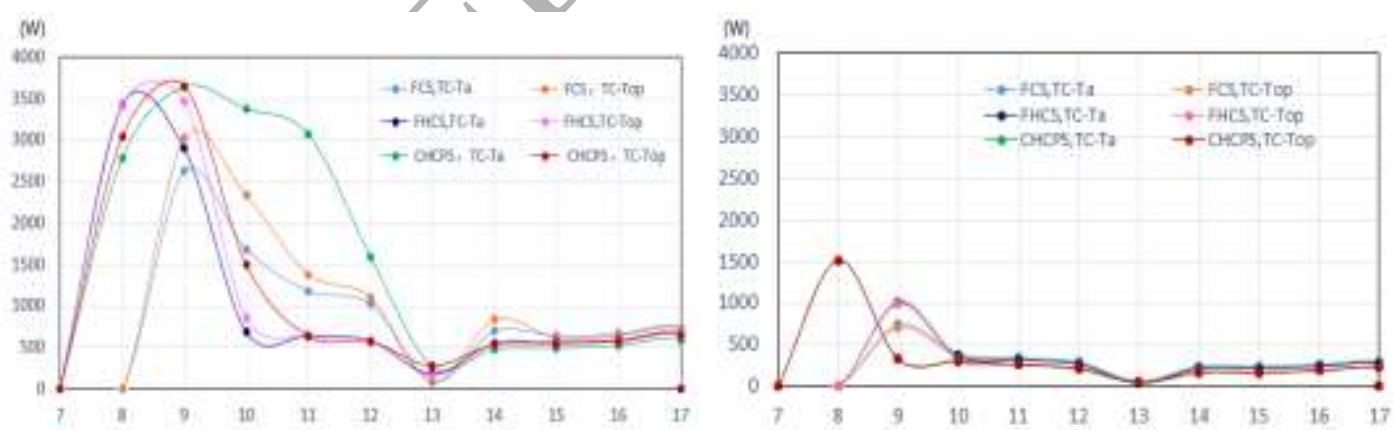

Total heating on $15^{\text {th }}$ Jan. (Monday)

Total heating on $17^{\text {th }}$ Jan. (Wednesday)
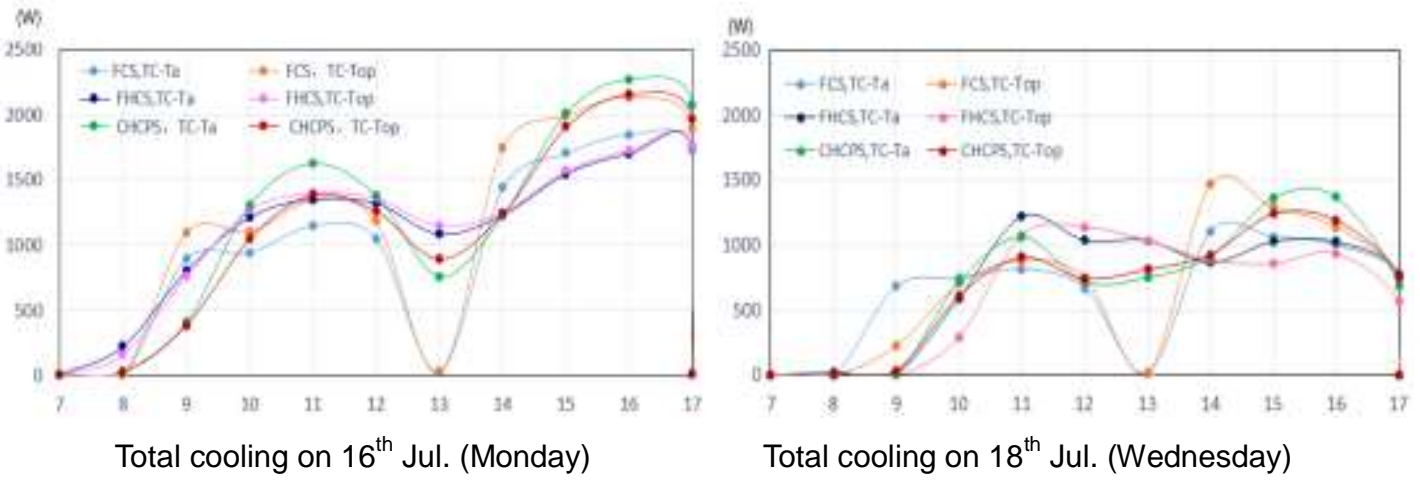


\section{(a) Copenhagen}
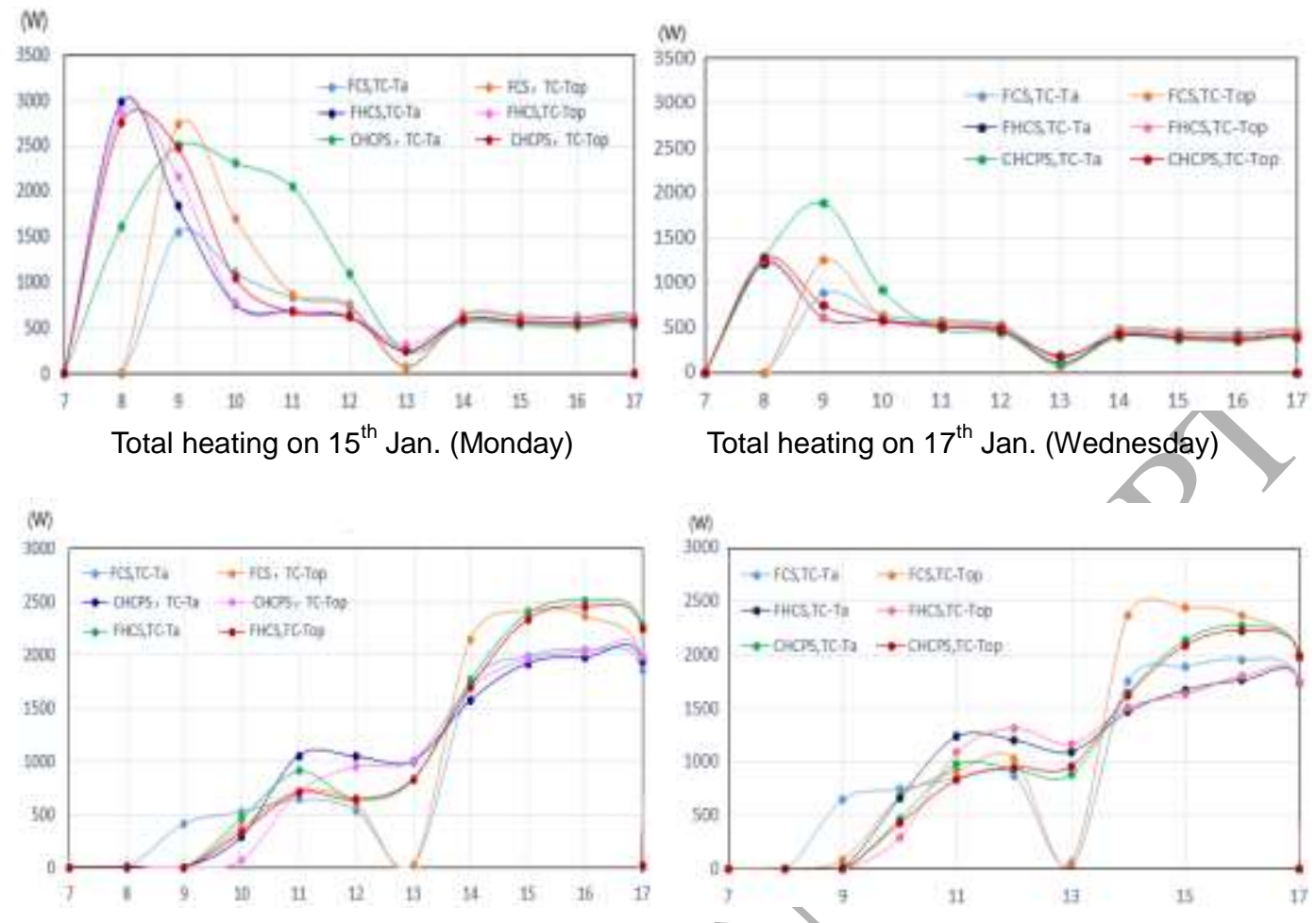

Total cooling on $16^{\text {th }}$ Jul. (Monday)

Total cooling on $18^{\text {th }}$ Jul. (Wednesday)

(b) Paris

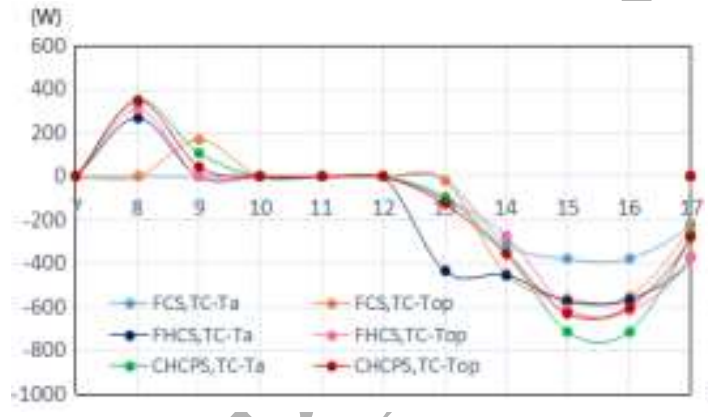

Total heating/cooling on $15^{\text {th }}$ Jan. (Monday)

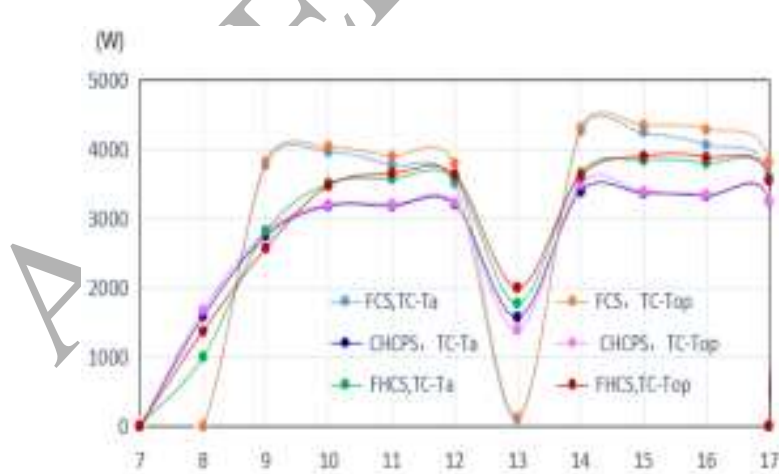

Total cooling on $16^{\text {th }}$ Jul. (Monday)

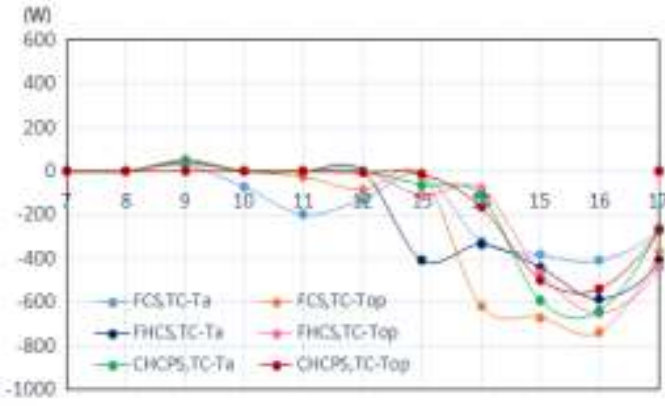

Total heating/cooling on $17^{\text {th }}$ Jan. (Wednesday)

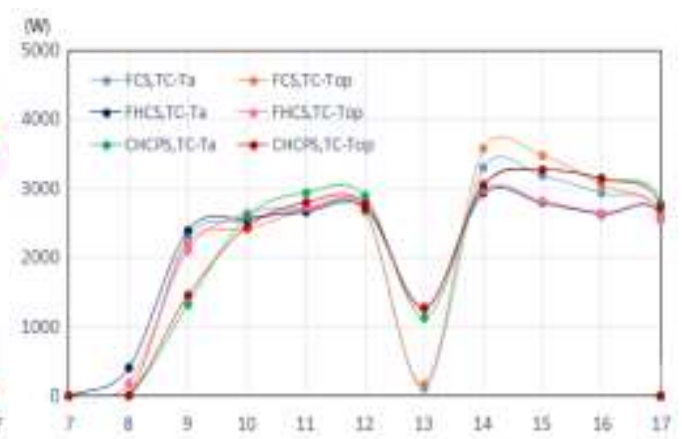

Total cooling on $18^{\text {th }}$ Jul. (Wednesday)

(c) Rome

Fig.4 Change of total heating/ cooling energy on typical days 


\subsection{Thermal conditions of offices}

\subsubsection{Statistics of thermal comfort}

The statistics of thermal comfort conditions in simulated cases are shown in Fig.5. There are 2000 occupancy hours in the simulated year and the percentage of comfort levels or category (Cat.) according to EN 15251 [6] among occupied hours are shown on the left. From this figure, thermal comfort of north office was better than south office in all cases. North office had more hours of Cat. I and less hours of Cat. IV than south office in corresponding cases. For north office, the maximum hours of Cat. IV was $44 \mathrm{~h}$ in allcases, which was less than $3 \%$ of the occupied hours; for south office, the number was $214 \mathrm{~h}$, almost $11 \%$ of the occupancy hours. The Cat. IV condition happened mostly because of overheating, e.g. the operative temperature was higher than $25^{\circ} \mathrm{C}$ in winter and $27^{\circ} \mathrm{C}$ in summer. In the building model, the north or south office had only one external wall and window and there were internal heat load during occupied hours. The solar radiation in the south office increases the risk of overheating. The south office would be more sensitive in response to the two controls. Based on this, south office would be discussed with more details.

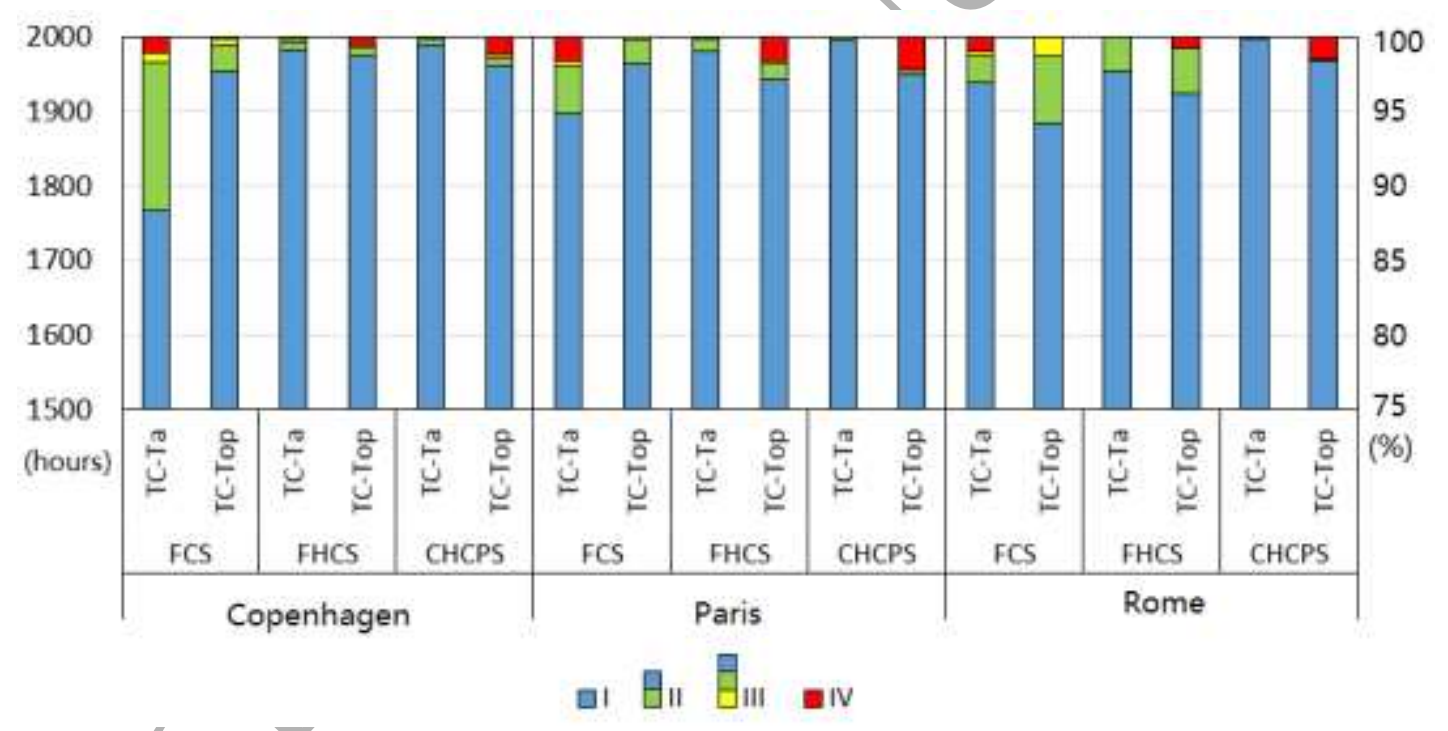

(a) North office 


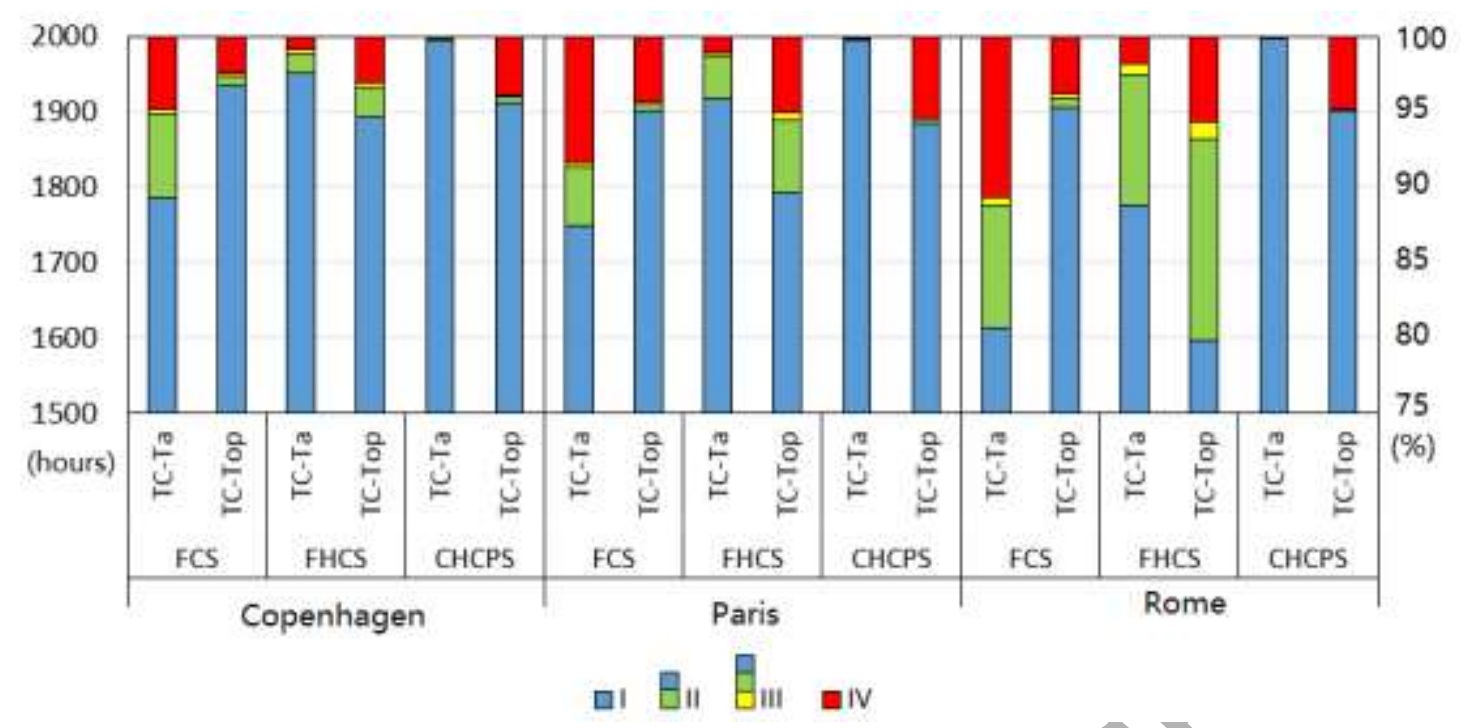

(b) South office

Fig.5 Statistics of thermal comfort levels

From Fig.5 (b), with TC- $\mathrm{T}_{\mathrm{op}}$, thermal comfort of FCS became better than that of TC- $\mathrm{T}_{\mathrm{a}}$ for all cities. Compared with TC- $\mathrm{T}_{\mathrm{a}}$, the hours of Cat. 1 increased $8.3 \%$ for building in Copenhagen, $8.8 \%$ for Paris and $14.2 \%$ for Rome. Meanwhile, the hours of Cat. IV decreased $2.5 \%$ for Copenhagen, 3.9\% for Paris and $7.1 \%$ for Rome. For radiant systems, the results were just the opposite that thermal comfort was better with $\mathrm{TC}-\mathrm{T}_{\mathrm{a}}$. There were more hours of Cat. I and fewer hours of Cat. IV with TC-T for both FHCS and CHCPS. The comparisons in the three cities showed the same results.

The European standard EN 15251 [6] suggests a methodology for long-term evaluation of the indoor environment. The standard accepts that indoor conditions can be outside the comfort range during $3-5 \%$ of the working hours per year. Taking into account upper limit later range $-5 \%$ of the working hours per year outside the Cat. III (normal level of expectation, $\mathrm{PPD}<15 \%$, corresponds to the Cat. C in EN ISO 7730 [5]), the north office met this requirement in all conditions. For south office, with FCS, when located in Paris and Rome, the proportion of Cat. IV hours was around $10 \%(8 \%$ in Paris and $11 \%$ in Rome). For all the other conditions, this proportion was less than or a little bit higher than $5 \%$ (with maximum of $5.7 \%$, which happened to FHCS with TC- $\mathrm{T}_{\text {op }}$ in Rome).

This analysis indicated that for the FCS, the use of TC- $\mathrm{T}_{\mathrm{a}}$ had poor thermal comfort condition in south office of Paris and Rome, while with TC- $\mathrm{T}_{\mathrm{op}}$ thermal comfort can be improved effectively. For radiant systems, the thermal comfort condition with TC- $\mathrm{T}_{\mathrm{a}}$ was better than that with TC-Top.

\subsection{2 $\mathrm{T}_{\mathrm{a}}$ and $\mathrm{T}_{\mathrm{op}}$ in south office}

The temperatures in the south office were compared further to explain the effect of two controls on FCS and two radiant systems. Fig. 6 shows the change of $T_{a}$ and $T_{o p}$ in south 
office on typical days. The sudden change from 12:00 to 13:00 was caused by the lunch break.

During cooling, on $16^{\text {th }}$ Jul., for FCS, $T_{\text {op }}$ was higher than $\mathrm{T}_{\mathrm{a}}$ in three locations. In summer, surface temperature of external wall and window in south office was higher than $T_{a}$, which led to higher mean radiant temperature and thus caused $\mathrm{T}_{\text {op }}$ higher than $\mathrm{T}_{\mathrm{a}}$. With TC- $\mathrm{T}_{\text {op }}$, $\mathrm{T}_{\mathrm{a}}$ became lower than that of TC- $\mathrm{T}_{\mathrm{a}}$. And more cooling energy should be supplied and thermal comfort would be better with TC- $\mathrm{T}_{\text {op }}$. For the two radiant systems, $\mathrm{T}_{\mathrm{a}}$ was higher than $T_{\text {op. }}$. The radiant system using cooling floor or ceiling, which has lower surface temperature than $T_{a}$, brought about lower mean radiant temperature. Thus with $T C-T_{o p}, T_{a}$ was higher than that of $\mathrm{TC}-\mathrm{T}_{\mathrm{a}}$ for radiant cooling systems. And less cooling energy could be supplied with TC-Top for these systems.

During heating, on $15^{\text {th }}$ Jan., in Rome, the change of $T_{a}$ and $T_{o p}$ for the two controls in three systems were similar to that in summer, especially in afternoon when cooling was supplied. The $T_{a} / T_{\text {op }}$ in south office were close to $25^{\circ} \mathrm{C}$, which meant that this office did not have a need for heating.

When the building was located in Copenhagen and Paris, $T_{a}$ was higher than $T_{\text {op }}$ using FCS, which made $\mathrm{T}_{\mathrm{a}}$ of TC- $\mathrm{T}_{\mathrm{op}}$ higher than that of TC- $\mathrm{T}_{\mathrm{a}}$. Therefore, more heating energy would be supplied using TC- $\mathrm{T}_{\mathrm{op}}$. In these two locations, for FHCS, $\mathrm{T}_{\mathrm{a}}$ was slightly higher than $\mathrm{T}_{\text {op }}$ and there was almost no difference between two controls. As floor was heated, the higher floor surface temperature could compensate the low temperature of other surfaces and increase mean radiant temperature. Therefore, the difference between $T_{a}$ and $T_{\text {op }}$ was small and the influence of two controls became similar too. This tendency was also true for CHCPS in Paris. For CHCPS in Copenhagen, results were slightly different on Monday. As Copenhagen was cold in winter, $T_{a}$ and $T_{o p}$ were about $18^{\circ} \mathrm{C}$ before occupancy, the ceiling panels would be heated at startup time. Because the surface temperature of ceiling panel was high (around $32^{\circ} \mathrm{C}$ ), the increase of $\mathrm{T}_{\text {op }}$ was faster than $\mathrm{T}_{\mathrm{a}}$. Thus, with $\mathrm{TC}-\mathrm{T}_{\text {op }}$ the heating time was shorter than that of $\mathrm{TC}-\mathrm{T}_{\mathrm{a}}$ (see Fig.4 (a)). And less heating energy was supplied by TC- $T_{\text {op }}$. With TC- $\mathrm{T}_{\mathrm{a}}, \mathrm{T}_{\mathrm{a}}$ and $\mathrm{T}_{\text {op }}$ became higher than that of $\mathrm{TC}^{-\mathrm{T}_{\mathrm{op}}}$ in the afternoon. This was why more heating energy was supplied to $\mathrm{CHCPS}$ with $\mathrm{TC}-\mathrm{T}_{\mathrm{a}}$ during heating.

Compared with Monday, $\mathrm{T}_{\mathrm{a}}$ and $\mathrm{T}_{\mathrm{op}}$ on Wednesday showed the same trend (though with less variation) in both heating and cooling season.
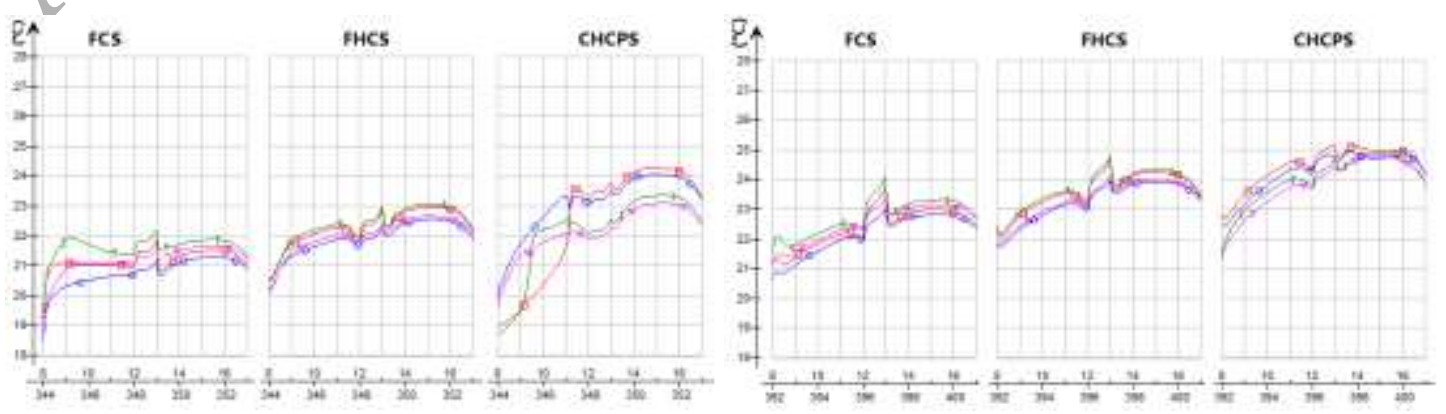
On $15^{\text {th }}$ (Monday) Jan.

On $17^{\text {th }}$ (Wednesday) Jan.
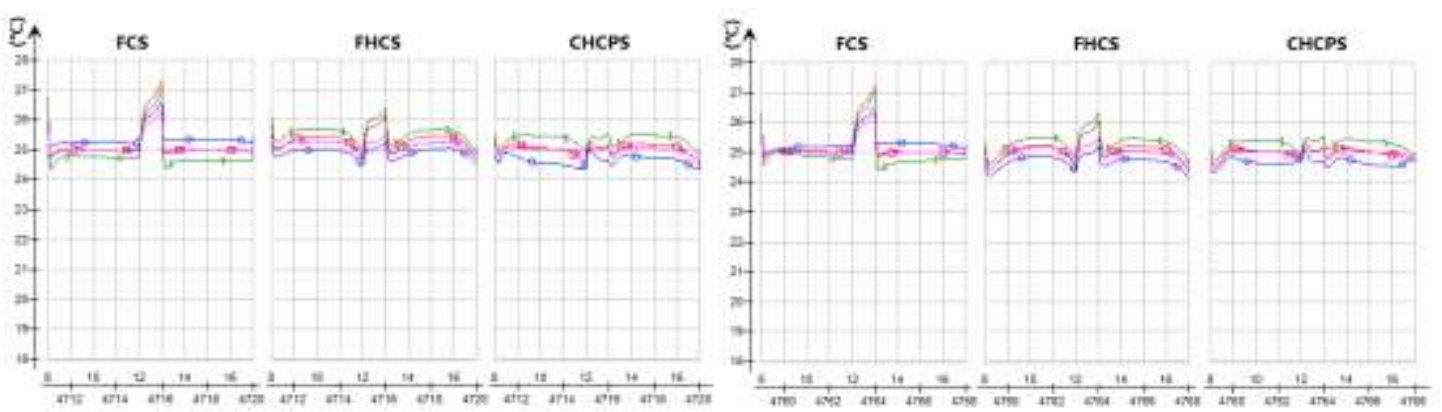

On $16^{\text {th }}$ (Monday) Jul.

On $18^{\text {th }}$ (Wednesday) Jul.

$\rightarrow \mathrm{D}-\mathrm{Ta}$, TC-Ta $\rightarrow \mathrm{Top}, \mathrm{TC}-\mathrm{Ta} \rightarrow \mathrm{Ta}$, TC-Top

- Top, TC-Top

(a) Copenhagen
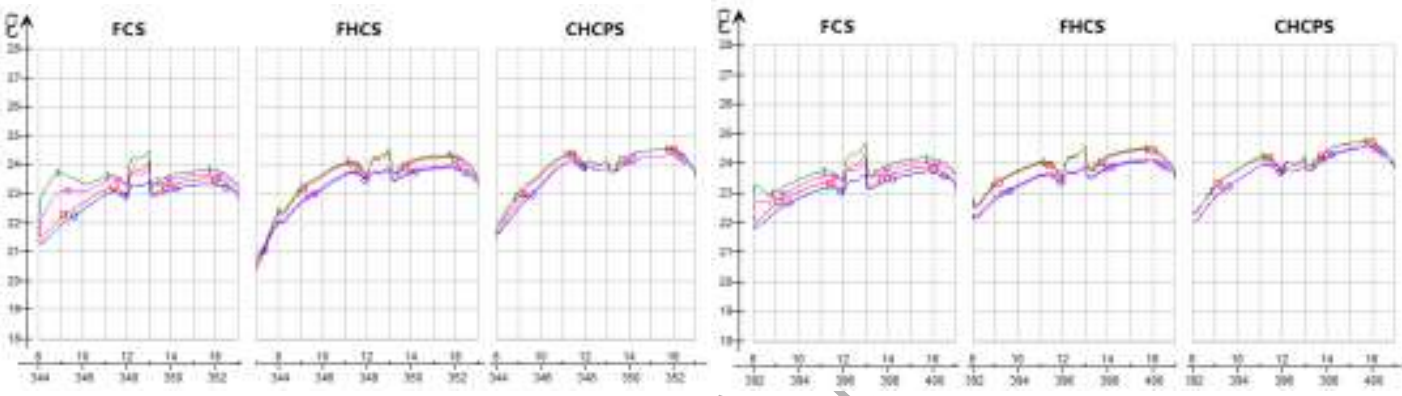
On $15^{\text {th }}$ Jan.

On $17^{\text {th }}$ (Wednesday) Jan.
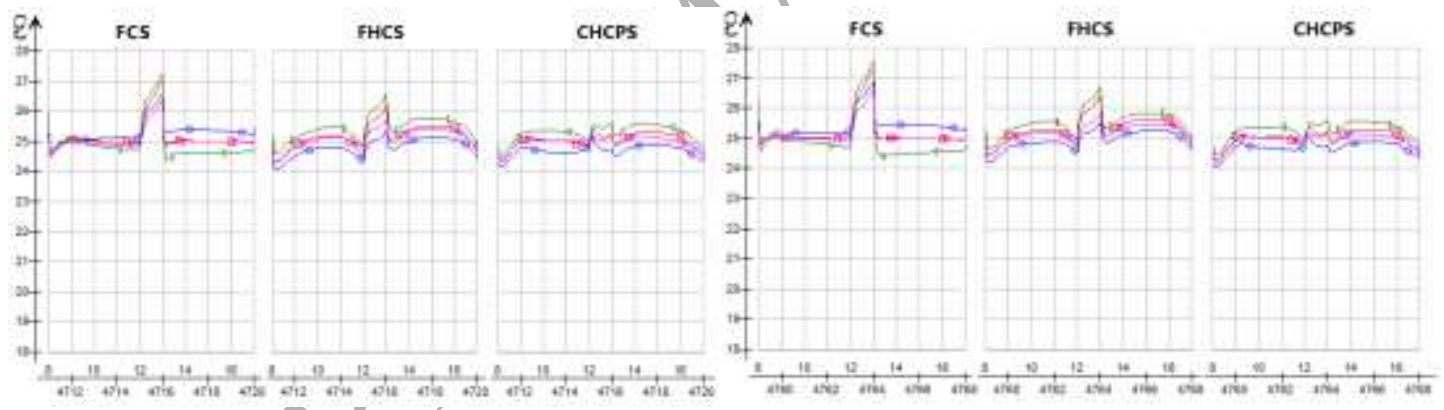

On $16^{\text {th }}$ (Monday) Jul.

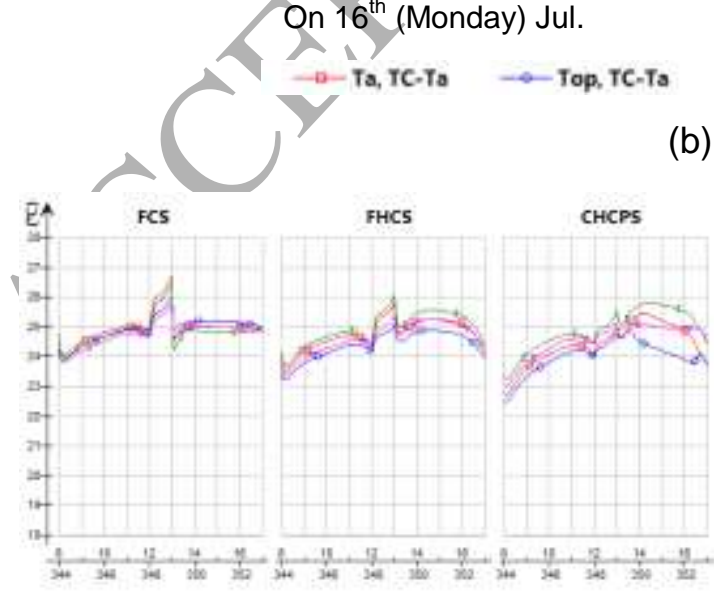

On $18^{\text {th }}$ (Wednesday) Jul.

$\rightarrow \mathrm{Ta}, \mathrm{TC}-\mathrm{Top}$

$$
\longrightarrow \text { Top, TC-Top }
$$

(b) Paris

On $15^{\text {th }}$ Jan.

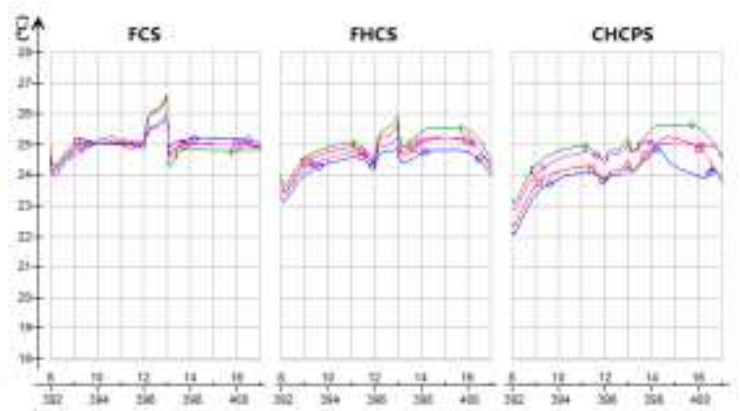

On $17^{\text {th }}$ (Wednesday) Jan. 


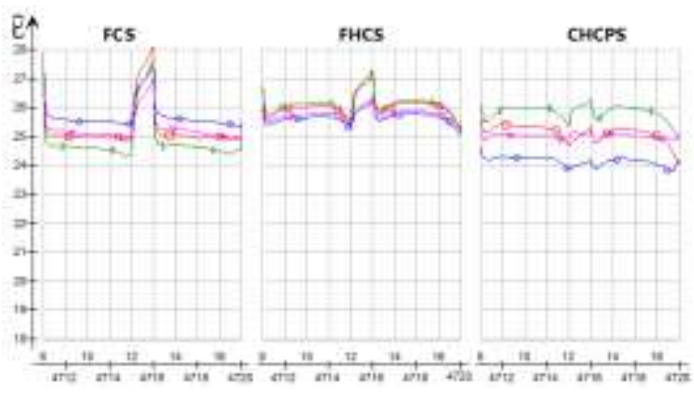

On $16^{\text {th }}$ (Monday) Jul.

$\rightarrow-\mathrm{Ta}, \mathrm{TC}-\mathrm{Ta} \rightarrow \mathrm{Top}, \mathrm{TC}-\mathrm{Ta}$

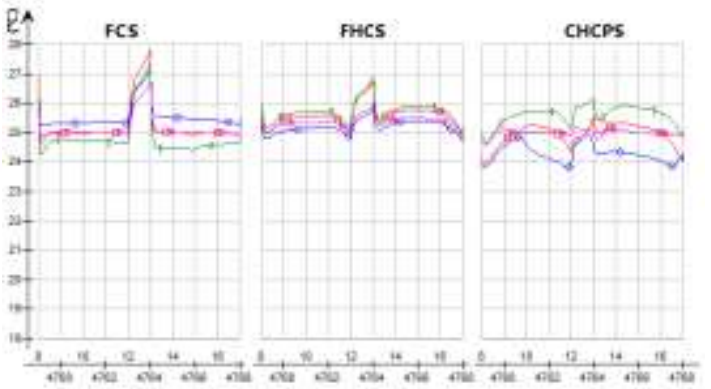

On $18^{\text {th }}$ (Wednesday) Jul.

$\longrightarrow$ Top, TC-Top

(c) Rome

Fig.6 Change of $T_{a}$ and $T_{\text {op }}$ in south office during occupied hours on typical days

Fig. 7 shows the mean value of $T_{a}, T_{o p}$ of every month (during occupied hours) and the temperature difference between $\mathrm{T}_{\mathrm{a}}$ and $\mathrm{T}_{\mathrm{op}}$ in south office, which can reflect the impact of different control methods on temperatures with the change of seasons.

From Fig.7 (a) and (b), the variation of $\mathrm{T}_{\mathrm{a}}$ and $\mathrm{T}_{\mathrm{op}}$ throughout the year were the most significant in Copenhagen, the changes became smaller in Paris, while Rome had the smallest changes. This was due to the climate difference in three locations.

For FCS, with $\mathrm{TC}-\mathrm{T}_{\mathrm{a}}$ the average $\mathrm{T}_{\mathrm{op}}$ and $\mathrm{T}_{\mathrm{a}}$ became lower than that of $\mathrm{TC}-\mathrm{T}_{\mathrm{op}}$ in heating (in Copenhagen and Paris) and changed to the opposite during cooling in all locations.

For FHCS, during heating average $\mathrm{T}_{\mathrm{a}}$ were basically the same under the two controls, and the difference between $\mathrm{T}_{\mathrm{op}}$ was also negligible (in Copenhagen and Paris); during cooling with $\mathrm{TC}-\mathrm{T}_{\mathrm{op}}$ both $\mathrm{T}_{\mathrm{a}}$ and $\mathrm{T}_{\mathrm{op}}$ tended to be a little higher than that of $\mathrm{TC}-\mathrm{T}_{\mathrm{a}}$ in the three locations.

For CHCPS, during heating (in Copenhagen and Paris) with TC- $\mathrm{T}_{\mathrm{a}}$ the average $\mathrm{T}_{\text {op }}$ and $\mathrm{T}_{\mathrm{a}}$ were higher than their counterpart of $\mathrm{TC}-\mathrm{T}_{\text {op }}$ and turned to be opposite in cooling period in all cities.

It can be noticed that in Copenhagen the difference of average $T_{o p} / T_{a}$ among the six cases in April and October became smaller than that of other months. This was because these two months were mild compared to others and the building had little demand for cooling and heating. This situation can also be found when located in Paris, in which the two mild months were February and November.

It can also be noticed that in all locations $T_{a}$ of FCS with TC- $T_{\text {op }}$ was the lowest, while $T_{\text {op }}$ of CHCPS with TC-T $\mathrm{T}_{\mathrm{a}}$ was the lowest during cooling. 


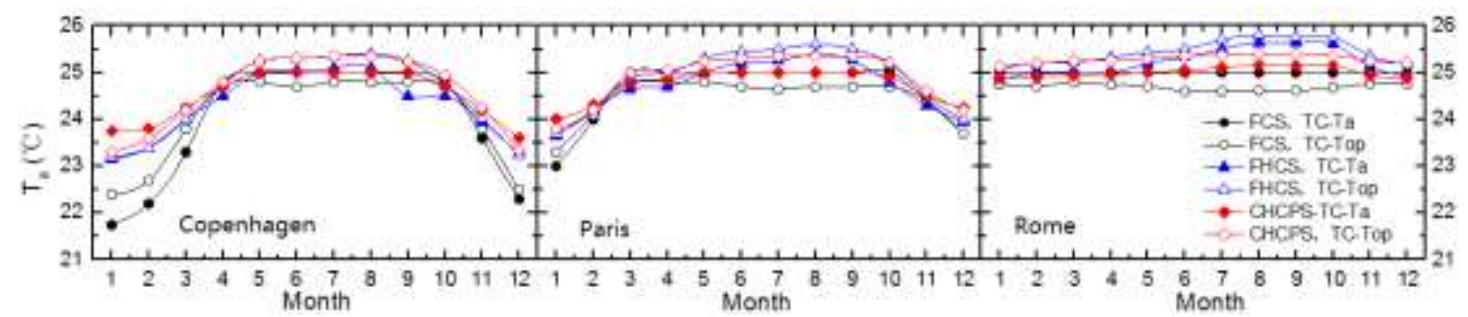

(a) $\mathrm{T}_{\mathrm{a}}$

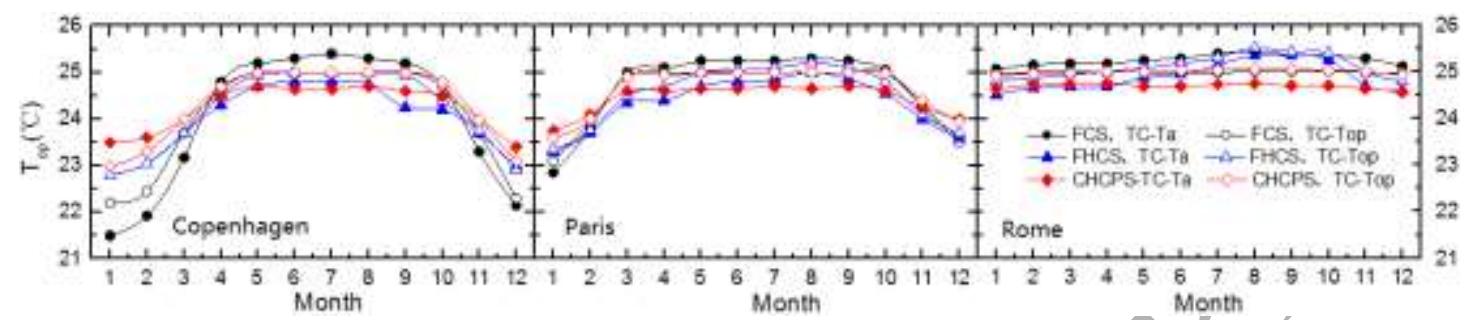

(b) $\mathrm{T}_{\mathrm{op}}$

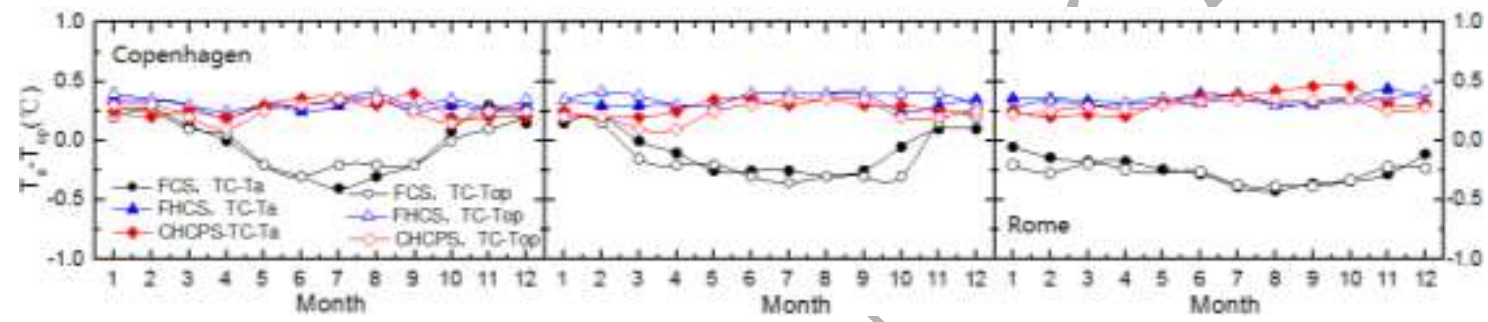

(c) Difference between $T_{2}$ and $T_{\text {op }}$

Fig.7 Monthly change of $T_{a}, T_{\text {op }}$ in south office

According to Fig.7 (c), the difference between $T_{a}$ and $T_{\text {op }}$ differed between FCS and radiant systems. For FCS, $T_{a}$ was higher than $T_{\text {op }}$ during heating (in Copenhagen and Paris), while $T_{\text {op }}$ was higher than $T_{a}$ during cooling for both controls in all locations. For radiant systems, $T_{a}$ was higher than $T_{o p}$ for the whole year. This was one of the difference between convective system and radiant system. As it had been stated before, when convective system was used, cool window would lead to lower $T_{\text {op }}$ in winter, while warm window would result in higher $\mathrm{T}_{\mathrm{op}}$ in summer. As to radiant system, it had heating surface to compensate cool window in winter and cool surface to compensate warm window in summer. Coexistence of cool and warm surfaces in radiant systems caused this difference. Besides, the difference between $T_{a}$ and $T_{\text {op }}$ was around $0.3 \mathrm{~K}$ for the two radiant systems, and the change with months and locations were not significant.

\subsubsection{PMV index}

The change of PMV in the south office on typical days are shown in Fig.8.

As it had been illustrated in Fig. 6 and 7 that $T_{a}$ and $T_{o p}$ in Rome were the highest among three cities during heating, the PMV in Rome was also the highest on winter days and was above zero for most of time. The PMV difference among six cases was small in Rome. 
For Paris, on typical heating days PMV became smaller and was around zero for most cases. When FCS was used, with TC- $\mathrm{T}_{\mathrm{a}}$ PMV was the lowest among the six simulations. For radiant systems, the PMV difference between the two controls was almost invisible.

When located in Copenhagen, there was a relatively larger difference of PMV among the six simulations in January. CHCPS with TC- $\mathrm{T}_{\mathrm{a}}$ had the highest PMV among all cases, while FCS with TC-T $T_{a}$ had the lowest. The PMV difference between the two cases was about 0.4. For CHCPS, PMV was closer to zero with TC-Ta than with TC-Top. For FHCS, the PMV difference between two controls was negligible. FCS would have better thermal comfort index when $\mathrm{TC}^{-} \mathrm{T}_{\text {op }}$ was used.

For cooling time, on typical days of Jul., radiant systems had lower PMV with TC- $\mathrm{T}_{\mathrm{a}}$ and FCS with this control had the opposite result. For same location, the PMV difference among the six cases was small except in Rome. CHCPS with TC- $\mathrm{T}_{\mathrm{a}}$ achieved lowest PMV for most conditions.

The change of PMV on Wednesdays were similar to that on Mondays in the three cities. The analysis of PMV showed the similar results with the analysis of $T_{a} / T_{\text {op }}$ based on typical days.

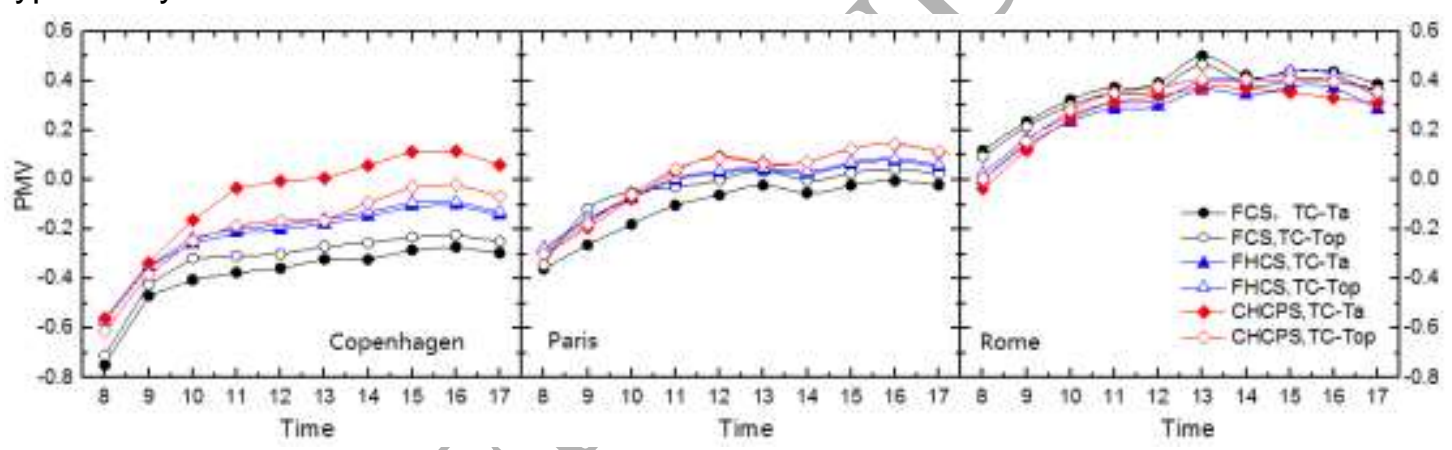

(a) $15^{\text {th }}$ Jan. (Monday)

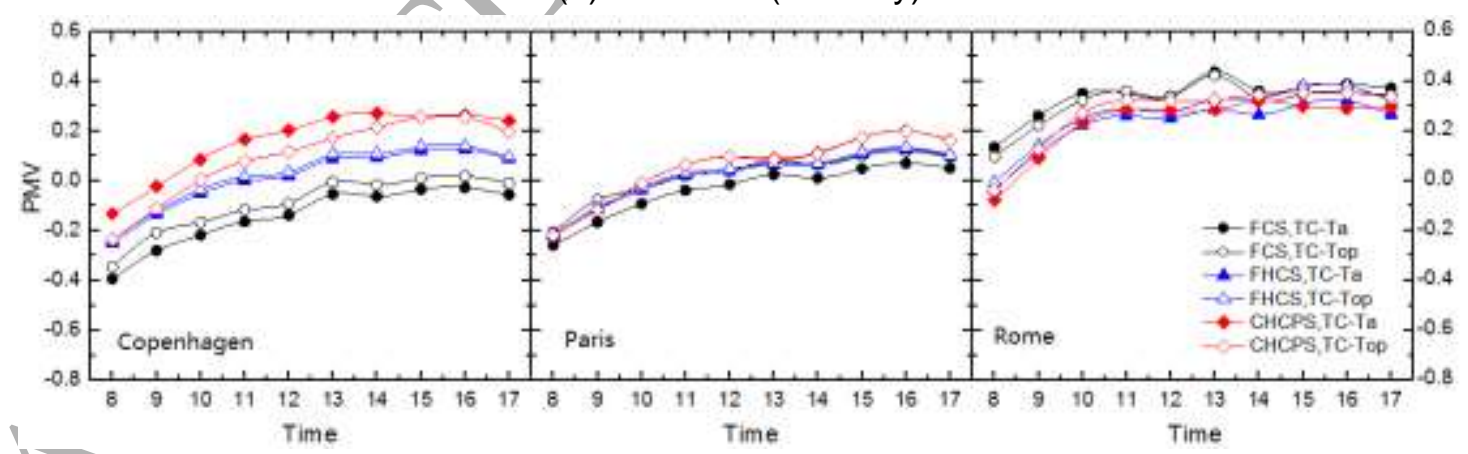

(b) $17^{\text {th }}$ Jan. (Wednesday) 


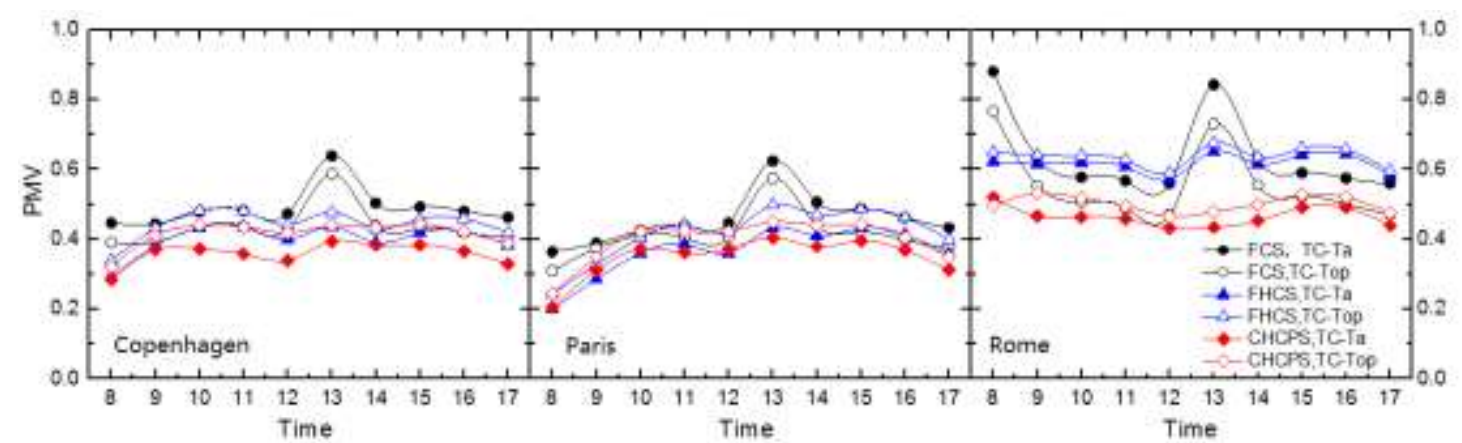

(c) $16^{\text {th }}$ Jul. (Monday)

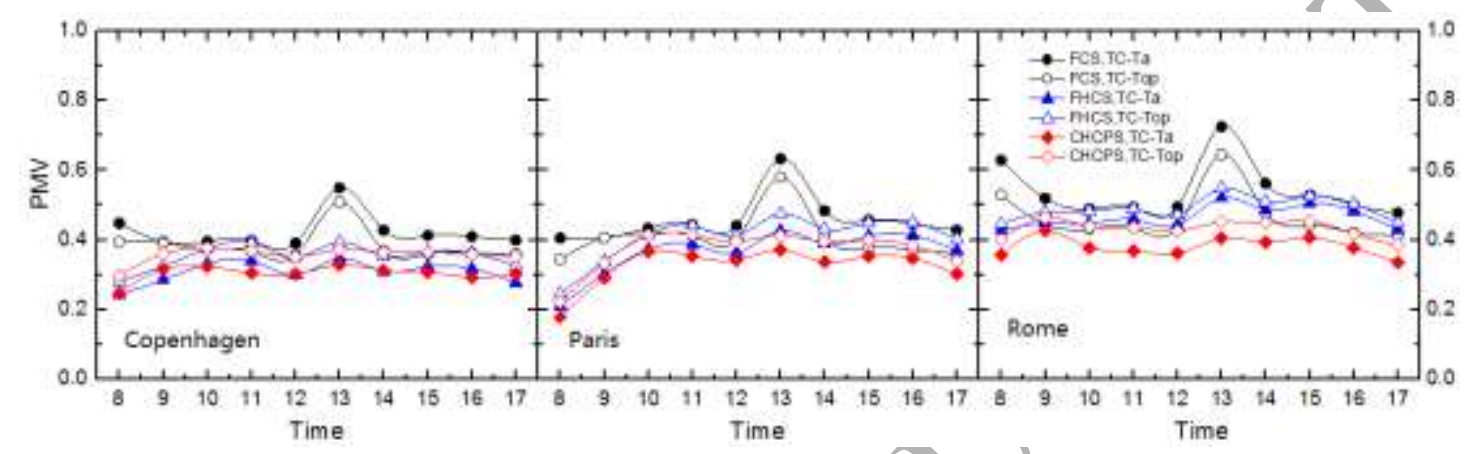

(d) $18^{\text {th }}$ Jul. (Wednesday)

Fig.8 Change of PMV index on typical days in south office

\section{General discussion}

As expected, the energy demand of each simulated system differed markedly among the tested locations. For same location, the energy use of three different systems shows some difference. For the same system under different control modes, energy use was not identical. In the same location, if combining the energy use with thermal comfort, it could be found that energy use can be connected with thermal comfort conditions. The corresponding cooling/heating energy supply will increase in the system or control mode that achieves better thermal comfort conditions. In the three systems, the control mode leading to better thermal comfort consumed more cooling and heating energy than the other one. For example, thermal comfort of FCS was highly improved using TC-T compared with $\mathrm{TC}_{\mathrm{a}} \mathrm{T}_{\mathrm{a}}$. Meanwhile, with $\mathrm{TC}-\mathrm{T}_{\mathrm{op}}$ both heating and cooling energy were increased in all locations for FCS system. The effect of TC- $\mathrm{T}_{\mathrm{a}}$ and $\mathrm{TC}-\mathrm{T}_{\mathrm{op}}$ on thermal comfort and energy use in the three climate conditions was almost the same.

In the analysis, much of the time that south office was out of comfort range was due to overheating. In the simulation, windows were kept closed all the time. In practice, night ventilation in hot season or natural ventilation during mild season can be applied to improve comfort and reduce energy use [20]. Especially for Rome, which had needs of cooling in winter, natural ventilation could completely meet the needs. When combined with natural ventilation, the comparison of the two control modes should be studied further. 
The results showed that non-radiant system of FCS had better thermal comfort conditions when TC- $\mathrm{T}_{\mathrm{op}}$ was used in all locations, while for radiant systems, thermal comfort will be improved using TC- $T_{a}$. During heating, FCS heated the air directly and $T_{r}$ was lower than $T_{a}$, while for cooling $T_{r}$ was higher than $T_{a}$. Under the same set point, $T_{a}$ would be higher in heating and lower in cooling with $\mathrm{TC}-\mathrm{T}_{\mathrm{op}}$ than that with $\mathrm{TC}-\mathrm{T}_{\mathrm{a}}$, thus the overall comfort was improved and more energy should be supplied. Radiant systems had a high temperature surface in heating and a low temperature surface in cooling, which caused difference compared to FCS. The simulation software calculated one $T_{r}$ and $T_{\text {op }}$ in a space. In practice, when the sensor is located in different positions (such as close to the window, radiant surface or be under solar radiation directly), the measured $T_{r}$ and $T_{o p}$ would be different. This may bring influence on the control of system and should be studied in the future.

The influence of control methods was more salient to south offices. South office is exposed to solar radiation that affects $T_{r}$, which will further influence $T_{o p}$. Even if the south and north office has same $T_{a}, T_{o p}$ would be different. That is why the use of $T_{a}$ and $T_{o p}$ sensors in control will have more significant impact on south offices. As to north office, the difference between the two controls were quite small. Based on this, different thermostat sensors can be considered for the control of the south and north spaces.

In the building model, the window occupied $30 \%$ of the total external wall in each office. When this ratio is changed (for example, external wall is constructed by glass curtain wall with ratio of $100 \%$ ) it would affect $T_{r}$ and $T_{\text {op }}$ in related spaces. The effect of two controls on energy and thermal comfort may be different [7]. Therefore, this factor should be taken into account in future studies.

In the simulation the radiant systems were turned on an hour earlier than FCS on weekdays considering that radiant systems might heat or cool the space slower than FCS. However, the energy use of FCS and radiant systems on typical days (Fig. 4) showed that heating/cooling energy was supplied at similar increasing trend at the beginning of working hours, which implied that it may be unnecessary to turn on the radiant system earlier.

Moreover, heating supply on $15^{\text {th }}$ Jan. in Copenhagen showed some difference between the two radiant systems. $T_{\text {op }}$ of $C H C P S$ grew faster than $T_{a}$ with both controls, while $T_{\text {op }}$ and $T_{a}$ increased similarly for FHCS. This was caused by the heat transfer difference of these two systems. FHCS releases more convective heat as heat goes upward naturally during heating and both $T_{a}$ and $T_{o p}$ increase at the same time, while CHCPS has less convective heat with downward warm surface and $T_{a}$ cannot be heated as quickly as $T_{o p}$ at the beginning of the system. Therefore, FHCS usually works better than CHCPS for heating. During cooling, the supply water temperature of FHCS was set as $15^{\circ} \mathrm{C}$ and $19{ }^{\circ} \mathrm{C}$ for CHCPS. In the simulation, the lowest temperature of cooling surface was $21.8^{\circ} \mathrm{C}$ for $\mathrm{FHCS}$ and $21.3^{\circ} \mathrm{C}$ for $\mathrm{CHCPS}$, which meant that ceiling panels can provide 
better cooling than floor surface. This explained the result that CHCPS had better thermal comfort conditions than FHCS under the same control conditions during cooling, especially when located in Rome.

\section{Conclusions}

The results of simulation showed that thermostat control based on air temperature and thermostat control based on operative temperature had different impact on fan-coil system and radiant systems.

- For fan-coil system, the use of thermostat control based on operative temperature was better for thermal comfort; but with higher energy use than that of thermostat control based on air temperature. When located in Paris and Rome, the application of thermostat control based on operative temperature can reduce hours of Cat. IV to less than $5 \%$ in south office. Meanwhile, total heating and cooling energy increased $14.3 \%$ in Paris and $12.7 \%$ in Rome.

- For radiant systems, the use of thermostat/control based on operative temperature will save heating and cooling energy $(3.3 \%$ to $8.3 \%$ depends on location and type of system) compared to the use of thermostat control based on air temperature. In south office, for floor heating/cooling system and radiant ceiling heating/cooling panel system, the thermal comfort condition with thermostat control based on operative temperature was within recommended criteria in international standards in most cases.

- The analysis indicated that the influence of two controls on thermal comfort were similar to north and south offices. However, the two controls had more influence on thermal comfort to south office than to north office.

- For all simulation cases, the thermal comfort of north office satisfied the demand of Cat. III and Cat. II in international standards.

- From the point of view of energy saving, thermostat control based on air temperature can be used in fan-coil system and thermostat control based on operative temperature be used in radiant system in north office.

For south office, the selection of thermostats should satisfy the requirement of thermal comfort and then energy saving can be considered.

Consequently, for south office thermostat control based on operative temperature is considered better for fan-coil system and can be more energy efficient when utilized in radiant systems.

\section{Acknowledgement}

This study has been financially supported by the National Natural Science Foundation of China (No.51678314 and No.51778305) and by the International Centre for Indoor 
Environment and Energy, DTU. The corresponding author is also supported by China Scholarship Council (201700810003).

\section{Conflict of Interest Statement}

We declare that we have no financial and personal relationships with other people or organizations that can inappropriately influence our work, there is no professional or other personal interest of any nature or kind in any product, service and/or company that could be construed as influencing the position presented in, or the review of, the manuscript entitled.

\section{References}

[1] Hardy, J.D. Physiological effects of high intensity infrared heating, ASHRAE Journal 1962; 4(11): 36 - 42.

[2] Gagge, A.P., G.M. Rappe and J.D. Hardy. The effective radiant field and operative temperature necessary for comfort with radiant heating, ASHRAE Journal 1967; 9(5): 63.

[3] Gagge, A.P. Standard operative temperature, a single measure of combined effect of radiant temperature, of ambient air temperature and of air movement on the human body in Temperature Measurement and Control in Science and Industry. Paper presented to Symposium of American Institute of Physics, 1941, Reinhold Publishing Corporation, New York, 544- 552.

[4] ASHRAE. ASHRAE Handbook-Fundamentals (SI). Chapter 8: Thermal Comfort, 2005.

[5] International Standard Organization for Standardization. EN ISO 7730: 2005, International standard: Ergonomics of the Thermal Environment-Analytical Determination of Thermal Comfort by Using Calculations of the PMV and PPD Indices and Local Thermal Comfort Criteria, Geneva, Switzerland.

[6] European Committee for Standardization. EN 15251:2007, Indoor Environmental Input Parameters for Design and Assessment of Energy Performance of Buildings Addressing Indoor Air Quality, Thermal Environment, Lighting and Acoustics, Brussels, Belgium.

[7] V. Jain, V. Garg, J. Mathur, S. Dhaka. $\square$ Effect of operative temperature based thermostat control as compared to air temperature based control on energy 
consumption in highly glazed buildings. Proceedings of Building Simulation 2011 November, Sydney: 2688-2695.

[8] C. Julien, A. Jerome and R. Philipe. Simulation of control options for HVAC management of a typical office building. Climate 2009, Lisbon, Portugal.

[9] J.I. Niu and J. Burnett. Integrating radiant/ operative temperature controls into building energy simulations. ASHRAE Transactions 1998; 104(2): 210-217.

[10] Georgios D. Kontes, Georgios I. Giannakis, Philip Horn et al. Using Thermostats for Indoor Climate Control in Office Buildings: The Effect on Thermal Comfort. Energies 2017; (10): 1368-22, DOI: 10.3390/en10091368.

[11] Kazanci O. B., Khovalyg D., \& Olesen B. W. (2017). Performance evaluation of radiant and convective cooling/heating systems \& Survey on HVAC related potential research themes for office buildings - Final Report. Kgs. Lyngby: Technical University of Denmark.

[12] Kazanci O. B., Khovalyg D., Takayoshi I., Uno Y., Ukiana T., \& Olesen B. W. (2018). Experimental comparison of the thermal indoor environment created by a radiant, and a combined radiant and convective cooling system. Proceedings of Roomvent \& Ventilation 2018. Espoo, Finland.

[13] Niclas Björsell, Axel Bring, Lars Eriksson et al. IDA indoor climate and energy - a new generation simulation tool. Building Simulation 1999, Kyoto, Japan, All 1-6.

[14] Bjarne Wilkens Olesen, Francesco Curro Dossi. Operation and Control of Activated Slab Heating and Cooling Systems. CIB World Building Congress, 2004.

[15] Jakub Kolarik, Jørn Toftum, Bjarne W. Olesen et al. Simulation of energy use, human thermal comfort and office work performance in buildings with moderately drifting operative temperatures. Energy \& Buildings 2011; 43: 2988-2997.

[16] Li, R., Yoshidomi, T., Ooka, R., \& Olesen, B. W. Case-study of thermo active building systems in Japanese climate. In Energy Procedia 2015; 78: 2959-2964. DOI: 10.1016/j.egypro.2015.11.679.

[17] ASHRAE. 2013 ASHRAE Handbook - Fundamentals, Atlanta, USA, 2013.

[18] CEN Report 1752, CEN Report: ventilation for buildings, Design criteria for the indoor environment, CEN/TC 156/WG 6, European Committee for Standardization, Brussels, Belgium, 1998.

[19] ASHRAE. ASHRAE Standard 55-2004, Thermal Environmental Conditions for Human Occupancy, Atlanta, USA, 2004.

[20] Ebrahim Solgi, Zahra Hamedani, Ruwan Fernando et al. A literature review of night ventilation strategies in buildings. Energy \& Buildings 2018; 173: 337-352, DOI: 10.1016/j.enbuild.2018.05.052. 